\title{
Prospects of Gene Knockouts in the Functional Study of MAMP-Triggered Immunity: A Review
}

\author{
Benedict C. Offor ${ }^{(D}$, Ian A. Dubery ${ }^{(}$and Lizelle A. Piater *(C) \\ Department of Biochemistry, University of Johannesburg, Auckland Park 2006, South Africa; \\ benedictoffor@gmail.com (B.C.O.); idubery@uj.ac.za (I.A.D.) \\ * Correspondence: lpiater@uj.ac.za; Tel.: +27-11-559-2403
}

Received: 5 March 2020; Accepted: 1 April 2020; Published: 6 April 2020

check for updates

\begin{abstract}
Plants depend on both preformed and inducible defence responses to defend themselves against biotic stresses stemming from pathogen attacks. In this regard, plants perceive pathogenic threats from the environment through pattern recognition receptors (PRRs) that recognise microbe-associated molecular patterns (MAMPs), and so induce plant defence responses against invading pathogens. Close to thirty PRR proteins have been identified in plants, however, the molecular mechanisms underlying MAMP perception by these receptors/receptor complexes are not fully understood. As such, knockout (KO) of genes that code for PRRs and co-receptors/defence-associated proteins is a valuable tool to study plant immunity. The loss of gene activity often causes changes in the phenotype of the model plant, allowing in vivo studies of gene function and associated biological mechanisms. Here, we review the functions of selected PRRs, brassinosteroid insensitive 1 (BRI1) associated receptor kinase 1 (BAK1) and other associated defence proteins that have been identified in plants, and also outline KO lines generated by T-DNA insertional mutagenesis as well as the effect on MAMP perception-and triggered immunity (MTI). In addition, we further review the role of membrane raft domains in flg22-induced MTI in Arabidopsis, due to the vital role in the activation of several proteins that are part of the membrane raft domain theory in this regard.
\end{abstract}

Keywords: BAK1; innate immunity; KO; MAMPs; membrane raft; MTI; PRRs; T-DNA

\section{Introduction}

\subsection{Plant Innate Immunity: An Overview}

Plants are continuously exposed to pathogen attack and this may lead to global losses in crop yields that, in turn, affect food security worldwide [1]. For instance, fungal-incited diseases are estimated to be responsible for 15-20\% crop losses per annum [2]. Furthermore, oomycetal Phytophtora infestans, bacterial Pseudomonas syringae pv. tomato (Pst) DC3000 and fungal Magnaporthe oryzae, have been shown to cause diseases and losses of potato, tomato and rice, respectively [3-5]. Plants use wax layers, cutin and lignified cell walls, as well as preformed and inducible antimicrobial metabolites, to protect themselves against pathogen attack. Microbes that evade these barriers are confronted by an innate immune system, since plants lack adaptive immunity [6-8]. The primary defence response of plants is achieved through the perception of conserved signatures referred to as microbe-associated molecular patterns (MAMPs) by pattern recognition receptors (PRRs), localised in the plasma membrane, which leads to MAMP-triggered immunity (MTI) [8,9] (Figure 1). These plant PRRs mostly belong to the receptor-like kinase (RLKs) or receptor-like protein (RLPs) families. In this regard, RLKs contain an extracellular ligand-binding ectodomain, a transmembrane domain, and an intracellular serine/threonine (Ser/Thr) kinase domain [8-10]. The RLPs, on the other hand, have a 
similar architecture, but lack the intracellular protein kinase domain [9]. The cytoplasmic receptor-like kinases (RLCKs) are not able to perceive MAMPs, because they lack an extracellular domain, but can interact with RLKs and participate in phosphorylation cascades, thereby leading to the activation of downstream innate immune response $[8,9,11]$.

MTI controls host microbial colonisation through the secretion of antimicrobial defence chemicals and nutrient deprivation of the attacking pathogen [12]. Several MAMPs such as epitopes from bacterial flagellin, elongation factor-thermo unstable (EF-Tu) and fungal chitin, have received much attention [13-15]. Other notable MAMPs under investigation are fungal ergosterol, ethylene-inducing xylanase (EIX), elicitin proteins, oomycetes $\beta$-glucan, bacterial cold shock protein (CSP), peptidoglycan (PGN), lipopolysaccharides (LPS), and necrosis and ethylene-inducing peptide 1-like proteins (NLPs) from multiple bacterial, fungal and oomycetal species [7,8,16-25]. The details, however, of the molecular mechanisms underlying MAMP perception by plant PRRs are elusive and appear to be different in each case, due to the unique physico-chemical properties of each ligand, specifically with regard to the binding kinetics and associated responses of the ligand: receptor interactions.

\subsection{Cellular Events Associated with Plant Defence}

The defence signalling events that occur when a PRR perceives its associated MAMP are illustrated in Figure 1, and include the induction of defence responses, such as reactive oxygen species (ROS) production and elevation of cytosolic calcium $\left(\left[\mathrm{Ca}^{2+}\right] \mathrm{cyt}\right)$. Here, $\mathrm{Ca}^{2+}$ binds to the first EF-hand motif in the N-terminal domain of respiratory burst oxidase homolog $\mathrm{D}$ (RbohD) and triggers ROS production [26]. Calcium-dependent protein kinase (CDPK), activated by the influx of calcium into the cytosol, thus contributes in the RbohD-dependent ROS production and induction of defence genes [27]. As an example, FLS2, as a well-studied PRR, forms a ligand (flg22)-induced complex with the co-receptor (BAK1) and recruits a RLCK (botrytis induced kinase 1, BIK1) [28]. BIK1 directly phosphorylates RbohD and contributes to the production of ROS and other downstream defence signalling [26]. Subsequent activation of signal transduction events linked to mitogen-activated protein kinases (MAPKs) leads to increases in the expression of defence-related genes, biosynthesis of pathogenesis-related (PR)-proteins, cell wall strengthening and callose deposition [24,29-32].

In order to abrogate MTI or the plant's primary defence responses, true microbes secrete effectors that interact with host targets, inhibit PRR-mediated signalling and cause infection, termed effector-triggered susceptibility (ETS). Pathogenic effectors may subdue MTI through different means, which include binding to PRRs and the disrupting of PRR-MAMP complexes, targeting PRR kinase domains to inhibit kinase activity, and trans-phosphorylation and autophosphorylation [33-35]. Additionally, effectors may bind PRR signal amplifiers like BAK1, and target transcription factors and MAPK signalling pathways [33-35]. In response, resistant plants carry polymorphic nucleotide-binding site leucine-rich repeat (NBS-LRR) resistance (R) proteins that recognise these effector-mediated perturbations. This triggers a secondary, more intense defence response, termed effector-triggered immunity (ETI), which is often associated with the hypersensitive response (HR) that protects plants against such pathogens $[29,31,36,37]$. Collectively, these processes are described by the zig-zag model of plant innate immunity, and demonstrate the co-evolutionary relationship between pathogens and host plants [29].

Impairment or abolishment of MTI may result in enhanced pathogen proliferation and increased plant susceptibility to pathogens (Figure 1) [33]. As such, gene knockout (KO) by e.g., transfer DNA (T-DNA) studies, where functional genes are made inoperative, represents a rational approach towards the investigation of MAMP perception by potential PRRs, as well as the interactions with cognate receptors and/or probable co-receptors. As such, in this review, we focus mainly on MAMPs from bacterial, fungal and oomycete pathogens, of which the cognate PRRs have been identified, and subsequent $\mathrm{KO}$ lines by the T-DNA mutagenesis used to study plant immunity. 


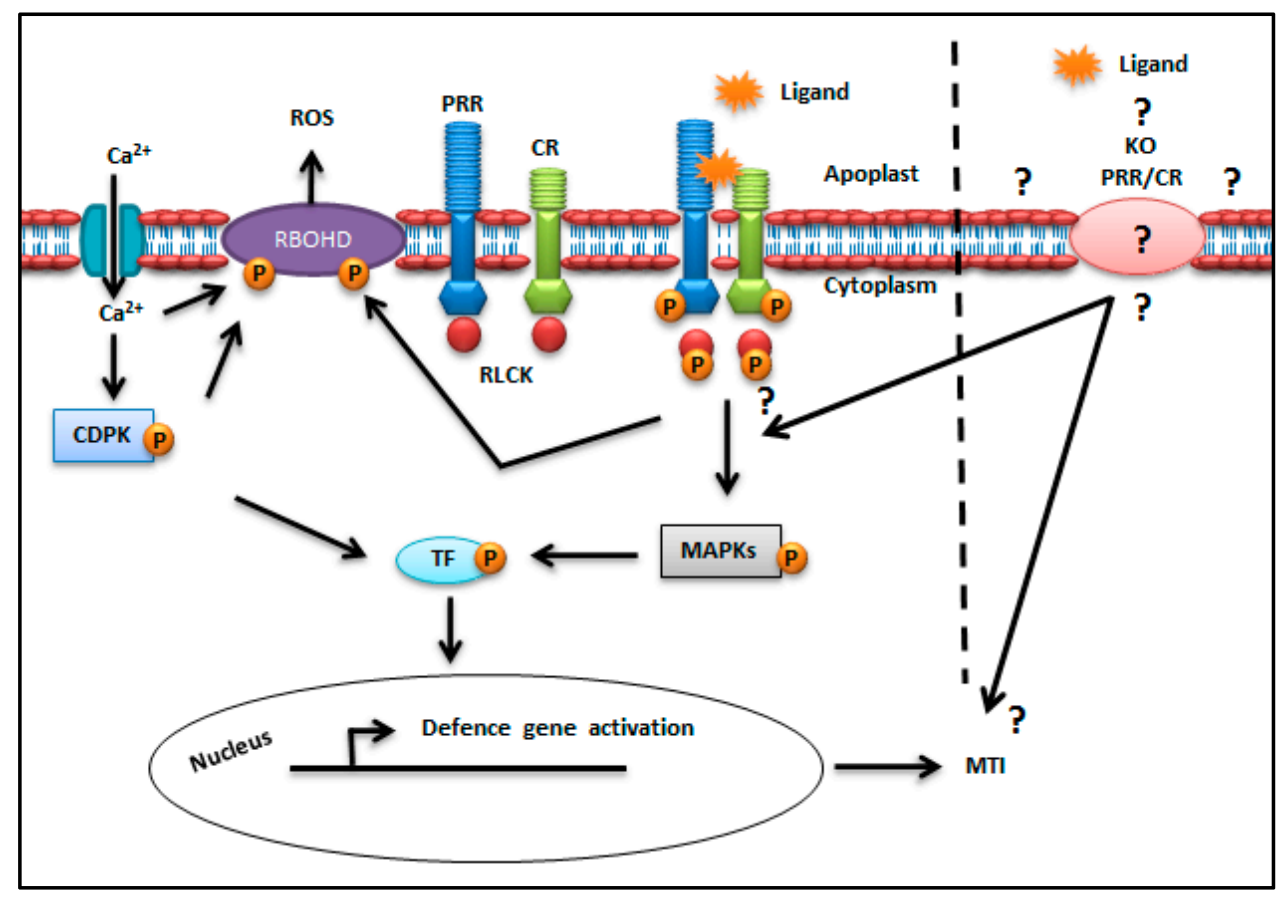

Figure 1. Generalised view of MAMP perception via PRRs, illustrating the potential impact of knockout (KO) effects that influence MAMP-triggered immunity. Upon MAMP (e.g., flg22) perception by a cognate PRR (e.g., in the case of FLS2 [28], the RLCK botrytis induced kinase1 (BIK1) dissociates from its complex with FLS2 and co-receptor BAK1. This leads to the activation of defence responses, such as ROS production, cytoplasmic $\mathrm{Ca}^{2+}$ influx, activation of downstream signalling kinases (MAPK and CDPK) and upregulation of defence genes. $\mathrm{KO}$ of the PRR and/or co-receptor (demarcated by the dotted line) may impair activation of downstream defence signalling, that could possibly lead to increased susceptibility of a plant to a pathogen. $\mathrm{P}=$ Phosphorylation, $\mathrm{RBOHD}=$ Respiratory burst oxidase homolog $\mathrm{D}, \mathrm{TF}=$ Transcription factor, $\mathrm{PRR}=$ Pattern recognition receptor, $\mathrm{CR}=\mathrm{Co}$-receptor, $\mathrm{MAMP}=$ Microbe-associated molecular pattern, $\mathrm{ROS}=$ Reactive oxygen species, $\mathrm{CDPK}=$ Calcium-dependent protein kinase, MAPK = Mitogen-activated protein kinase, $\mathrm{RLCK}=$ Receptor-like cytoplasmic kinase, MTI = MAMP-triggered immunity.

\section{T-DNA Knockout and Other Mutagenesis Technologies}

Mutant plants generated by disrupting genes that code for PRRs have been widely adopted in plant research. Since the main objective in this field is to improve crop production, mutant analysis to assay gene disruption effects is a useful tool [38]. T-DNA insertion into an intron/exon (should the intron insertion not be affected by splicing mechanisms) will disrupt gene expression, a phenomenon commonly referred to as "knockout" or null mutations [39]. The completion of the Arabidopsis genome sequence [40] has led to exponential interest in the use of KO methodologies as a reverse genetics approach to study plant metabolism [41]. T-DNA insertional mutagenesis has undisputed performance in plant research, despite rivalry from other gene KO systems such as RNA interference (RNAi) [42], zinc finger nucleases (ZFNs) [43], transcription activator-like effector nucleases (TALENs) [44,45] and clustered regularly interspaced short palindromic repeats (CRISPR)/CRISPR-associated protein 9 (Cas9) technology $[46,47]$.

Insertional mutagenesis has the advantage of targeting individual genes within a closely related family, such that the function of these can be investigated [41]. Transposon mutagenesis is part of insertional mutagenesis where mobile transposons are removed from an original genomic location to another genomic position, by the aid of the transposon-encoded transposase enzyme [48]. That may disrupt the gene-coding region and concomitant loss-of-function phenotypes of that particular gene. A transposon mutagenesis screen has a number of advantages, which include high throughput, easy 
identification and provision of information into an organism's genetic network [48]. Nevertheless, transposon insertion also has a number of draw backs. In this regard, intronic insertion of a transposon can be spliced out, leading to unsuccessful or unstable insertional mutagenesis. Furthermore, cryptic splice sites in the transposon's sequence could lead in the generation of truncated transcripts [48].

T-DNA, on the other hand, is a short segment of DNA that is transferred from a bacterial tumour inducing (Ti) plasmid to the plant genome, when a plant is infected by Agrobacterium tumefaciens $[41,49,50]$. T-DNA insertional mutagenesis helps in the functional identification of genes that are responsible for an observed plant phenotype. Pertaining hitherto, Tables 1 and 2 show selected plant PRRs, BAK1 and other associated defence proteins, the T-DNA KO genes and roles in plant MTI. T-DNA does not only disrupt the genes into which it is inserted, but also serves as a marker in the identification of the mutant [50]. The subsequent PCR-based screening of genomic DNA is a simple tool to select homozygous plants for the T-DNA insertional mutagens [38,39]. Here, insertions in the target genes are detected by the use of a combination of gene-specific and T-DNA-specific primers. As such, in this review, we focus on T-DNA insertional mutagenesis of well-studied PRRs, co-receptors and other associated proteins, and discuss the contribution in the study of MTI.

T-DNA is flanked by $25 \mathrm{bp}$ right border (RB) and left border (LB) sequences, respectively, that enables the replacement of native DNA with DNA of interest to enhance genetic engineering [51]. Successful transfer of the T-DNA into the host plant's nuclear genome requires virulence (vir) genes $(\operatorname{vir} \mathrm{A}, \operatorname{vir} \mathrm{B}, \operatorname{vir} \mathrm{C}$, $\operatorname{vir} \mathrm{D}, \operatorname{vir} \mathrm{E}, \operatorname{vir} \mathrm{F}$, and $\operatorname{vir} \mathrm{G})[51,52]$. VirD1 and $\operatorname{Vir} \mathrm{D} 2$ endonucleases, which cut the bottom part of the T-DNA border, release the single stranded DNA (T-strand) and attach to the $5^{\prime}$ end [53]. The T-strand is escorted through the cytoplasm into the nucleus by a complex (T-complex) that includes VirD2, VirE2 and VirF [51]. The T-DNA is then integrated into the plant genome in various orientations (full-length, truncated or multiple T-DNAs) and requires plant proteins [53]. Subsequently, T-DNA insertion alters both the genomic and epigenomic landscape of Arabidopsis T-DNA insertion lines [54]. The advantage of using T-DNA insertion is that there is no transposition after integration within the genome, and it is chemically and physically stable through multiple generations [39]. Additionally, mutations that are homozygously lethal can be obtained and maintained in a population in the form of heterozygous plants [50]. There are, however, also a number of disadvantages associated with T-DNA insertional mutagenesis. These include multiple T-DNA insertions, different insertion sizes and chromosomal rearrangements [54,55]. In addition, T-DNA insertion has been reported to induce the decreased expression of adjacent genes in Arabidopsis [56]. Another major limitation of T-DNA mutagenesis, like all gene disruption approaches, is the possibility of no phenotypic alteration due to gene duplication or redundancy, especially in genes required for early embryogenesis or gametophytic development [49,50]. Notably, over 70\% of Arabidopsis genes are present in more than one copy $[40,41]$. To overcome these limitations, the generation of double or multiple mutations in a group of related genes is important in observing phenotypic alteration [49]. In this regard, expression patterns using specialised vectors with modified insertional elements can be used to identify redundant genes [50].

\section{Membrane Raft Domains in the flg22-Mediated Defence Response}

The Sanger and Nicholson fluid-mosaic model [57] describes the plasma membrane (PM) as comprised of a lipid bilayer, with integral and peripheral proteins randomly distributed within the membrane. Thereafter, the membrane raft concept, first introduced by Simons and Ikonen [58], defined specific regions of the plasma membrane with high concentrations of specific lipids (sphingolipids, sterols) and proteins that are involved in both membrane trafficking and signalling. Membrane rafts are formed through lipid-lipid interactions, where sphingolipids on the outer leaflet of the membrane interact with sterols, such as either cholesterol in mammalian cells or phytosterols in plant cells [58-60]. These microdomains are dynamic and highly organised at the nanoscale (10-200 $\mathrm{nm}$ in diameter) level within various parts of the membrane, and can be stimulated into larger and more stable raft domains by lipid-lipid—as well as protein-lipid—and protein-protein interactions [59,61,62]. 
Membrane rafts contain a high content of saturated fatty acids within the phospholipids, as well as cholesterol, compared to the non-raft regions of the PM, thereby producing a liquid-ordered (Lo) phase [63,64]. This tight packing of the lipids into a less fluid Lo phase confers detergent-resistant properties to membrane rafts [61]. At low temperature $\left(4^{\circ} \mathrm{C}\right)$, the Lo phase structures of rafts can be recovered from membrane fractions as a consequence of the tight packing of the lipids and insolubility to non-ionic detergent (Triton X100), and are therefore referred to as 'detergent-insoluble membranes' (DIMs) [61,65]. Functionally, membrane rafts play regulatory roles in signal transduction, endocytosis and exocytosis, cell adhesion, actin cytoskeleton organisation and cell trafficking [59,64-66].

Proteins associated with membrane rafts include G-proteins, protein kinases and glycophosphatidyl inositol (GPI)-anchored proteins that are involved in signal transduction $[62,64,67]$. As such, membrane rafts are believed to play vital roles as signal transduction platforms during plant biotic/abiotic stress [65], and are proposed to be the hub for PM-localised receptor proteins (like PRRs) and co-receptor complexes that are involved in MAMP perception and defence signalling in plants $[65,66]$. Consistently, the induction of proteins was observed in DIMs prepared from Arabidopsis, tobacco and rice, upon treatment with bacterial flg22, oomycetal cryptogein and fungal chitin, respectively [68-70]. Using quantitative proteomics, Kierszniowska et al. [67] identified proteins that are involved in signalling, such as receptor kinases, G-proteins and calcium signalling proteins in Arabidopsis thaliana rafts. Similarly, flg22 induced proteins, such as proton pump ATPases and RLKs including FLS2 in DIMs of $A$. thaliana cells [70].

Figure 2 demonstrates a model of the activation of the RbohD enzyme upon flg22 perception by FLS2 and subsequent signalling in raft domains of $A$. thaliana [64-66]. In non-treated A. thaliana cells, FLS2 is located in non-raft domains or detergent-soluble domains (DSMs), whereas inactive RbohD enzymes, phosphatidylinositol (4,5)-bisphosphate-specific phospholipase C (PIP2-PLC), diacylglycerol kinase (DGK) and typical raft proteins, such as remorin (REM), are localised inside rafts or DIMs. In pre-active states, both FLS2 and BAK1 are located in different regulatory protein complexes. For example, FLS2 is found in complex with the RLCK, BIK1, whereas BAK1 is associated in complex with BAK1-interacting receptor-like kinases (BIR1, BIR2 or BIR3) [28,71,72]. Immediately upon flg22 treatment of the cells, FLS2 shifts from DSMs to DIMs, forms a complex with BAK1, and recruits BIK1 that leads to the activation of RbohD enzymes through a series of phosphorylation events and concomitant downstream defence signalling. Thus, the recruitment of regulators of $\mathrm{RbohD}$, such as the 14.3.3 protein, the Rac G protein (a small GTPase immunoregulator) and the phospholipid, phosphatidic acid (PA), to the N-terminus of RbohD, leads to its activation [28,65,66,68-70,73,74]. In addition, other proteins reported to be abundant in DIMs upon flg22 elicitation include channel proteins, RLKs, and transporters (e.g., ABC transporter and $\mathrm{H}^{+}$-ATPase AHA1) [73]. RLKs, including BAK1, have also been identified in the DIMs of tobacco suspension cells [75]. Although there has been much research interest in membrane rafts, many controversies exist regarding their existence and function [60], and more studies are needed to substantially understand their role in, and contribution to, plant defence signalling. 




Figure 2. A model for localisation of PRRs in membrane rafts upon flg22 MAMP elicitation in A. thaliana. (a) Non-stimulated cells contain FLS2, BAK1 and other RLKs in non-raft domains (dominated by phospholipids), with inactive RbohD, PIP2-PLC, DGK typical raft protein markers (like remorin). (b) In flg22 treated cells, FLS2 forms a complex with BAK1 in DIMs (dominated by sphingolipids and sterols), that follows with recruitment of the RLCK BIK1 to the FLS2-BAK1 complex. Transphosphorylation events lead to RbohD activation and downstream defence signalling. Other components of DIM include CDPK, Phospholipase D (PLD), Phospholipase C (PLC), small G protein (Rac) and channel proteins (adapted from $[28,65,66,73])$.

\section{Pattern Recognition Receptors in MTI}

PRRs play key roles in plant defences against microbes. Figure 3 illustrates the different structural configurations of selected PRRs in plants, to demonstrate the different ectodomains that are involved in MTI. Several PRRs have been characterised in different plants, including EF-Tu receptor (EFR) and flagellin sensitive 2 (FLS2), which are both RLKs [14,76,77]. RLPs, such as the chitin elicitor-binding protein (CEBiP) identified in rice, require an additional protein (chitin elicitor receptor kinase 1; CERK1), with cytoplasmic kinase activity to trigger chitin defence signalling [78,79]. RLKs and RLPs are classified into subfamilies, depending on the motifs or domains of the ectodomains [36]. These domains include leucine-rich repeat (LRR), lysin M (LysM) or lectin (Lec), used to bind specifically to ligands [9,80]. A number of RLKs and RLPs use LRRs to bind MAMP epitopes. For example, FLS2, is a LRR-RLK that binds bacterial flg22 (an epitope in flagellin) and triggers immune defence signalling [76,81]. On the other hand, cold shock protein receptor (NbCSPR), a LRR-RLP, associates with BAK1 and, upon cold shock protein epitope (csp22) treatment, induces defence responses in Nicotiana benthamiana [82]. In tomato, cold shock receptor (CORE), a LRR-RLK, recognises bacterial csp22 and triggers defence responses [83]. These indicate the presence of two modes of CSP perception in the Solanaceae. 
Transgenic expression of NbCSPR in A. thaliana conferred csp22 responsiveness and resistance to Pst DC3000 bacteria. Other notable LRR-RLKs involved in MTI are rice XA21 and tomato FLS3, that recognise the bacterial peptides required for the activation of XA21-mediated immunity $X(\operatorname{Rax} X)$ and flgII-28, respectively $[84,85]$. Other examples of LRR-RLPs include Arabidopsis receptor-like protein 23 (RLP23) and tomato elicitin response (ELR), that recognise nlp20 and oomycetes elicitins $[17,86]$.

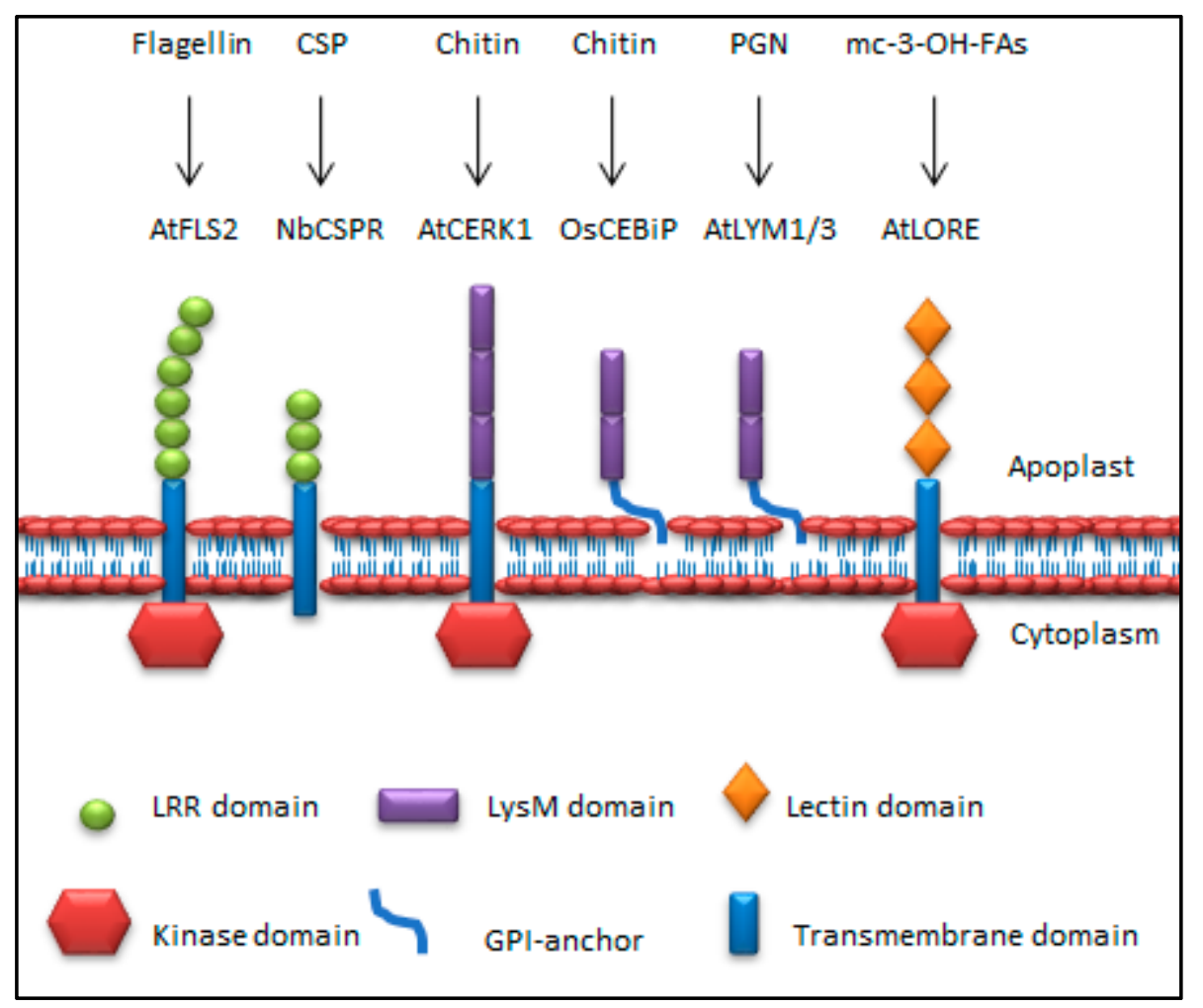

Figure 3. Structural configuration of plant PRRs. PRRs use different conserved external surfaces such as LRR-, LysM- or lectin domains to recognise MAMPs. Following, the transmembrane domain relays the perceived signal into the cell for the kinase domain to perform PRR activation, phosphorylation of downstream defence-related proteins and subsequent MTI induction. LRR = leucine-rich repeat, LysM = lysine motif, GPI = glycophosphatidyl inositol.

PRRs with LysM ectodomains are also part of both RLK and RLP families. LysM-RLK CERK1 uses such motifs on its extracellular domain to interact with the MAMP chitin in A. thaliana [15], while LysM-containing RLPs, LYM1/LYM3, perceive PGN in A. thaliana [87]. Notably, LYM1/3 and LYM2 RLPs, which are Arabidopsis homologs of OsCEBiP, possess a unique glycophosphatidyl inositol (GPI) anchor used to attach the receptors in the plasma membrane bilayer $[12,87,88]$. Additional examples of LysM-RLKs include Arabidopsis LYK5 and LYK4, which are involved in fungal chitin perception and defence signalling [89,90], while members of LysM-RLPs include the rice LYP4 and LYP6, that recognise fungal chitin and bacterial PGN respectively [91].

The bulb-type (B-type) lectin S-domain (SD)-1 RLK, lipooligosaccharide-specific reduced elicitation (LORE), which is a lectin (Lec)-RLK, was reported to sense the bacterial Xanthomonas and Pseudomonas LPS, and to activate MTI in Arabidopsis [92]. However, recently Kutschera et al. [93] reported that 3-hydroxy fatty acids that co-purified with LPS induced a LORE-dependent defence response in A. thaliana. Thus, LORE is not the receptor for LPS. Relatedly, Sanabria et al. [94] proposed an LPS-responsive N. tabacum S-domain RLK (Nt-Sd-RLK) gene encoding conserved B-lectin, S- and PAN domains to be involved in LPS perception. These authors proposed that S-domain RLK MAMP perception and signal transduction could be via direct ligand recognition and binding of carbohydrate 
epitopes, or by indirect ligand-induced conformational changes, dimerisation or recruitment of a co-receptor to initiate phosphorylation events that lead to the activation of defence signalling [94-97].

Although this review is focused on mutant lines where specific PRRs have been knocked-out, it is important to note that most RLKs and RLPs do not function in isolation, but mostly act together with associated proteins that participate in defence signal transduction upon MAMP perception. In this regard, the RLK co-receptor BAK1 has been shown to be recruited upon MAMP perception to modulate defence signalling $[96,98,99]$. In addition to BAK1, other proteins might be recruited to the PRRs to form a functional recognition complex and regulate immune signalling $[74,100]$. For example, SOBIR1, an adaptor for LRR-RLPs, regulates cell death and innate immunity in Arabidopsis and tomato [101-103], while FERONIA (FER) and IMPAIRED OOMYCETE SUSCEPTIBILITY1 (IOS1), both malectin-like RLKs, form ligand-induced complexes with PRRs and regulate MTI in Arabidopsis [104,105].

Additional protein-protein interactions and motifs deserve some mention, particularly to highlight the need to regulate PRR activities, as well as turnover, in order to keep immune signalling in check. In this regard, an elicitor-responsive Armadillo repeat protein (GhARM) from cotton (Gossypium hirsutum) regulates cell wall-derived Verticillium dahliae elicitor responsiveness and contains three consecutive ARM repeats that, in association with certain RLKs or co-receptors, activate plant defence signalling [106]. Upon flg22 treatment, the Arabidopsis U-box E3 ubiquitin ligase, PUB13, uses a C-terminal ARM repeat domain to interact and ubiquitinate FLS2 in a BAK1-dependent manner [107]. Additionally, flg22-mediated FLS2 internalisation and endocytosis depends on cytoskeleton, receptor activation, and proteasome functions. Mutation at the threonine 867 of FLS2, proposed to bind flg22, showed impairment in flg22 signalling, as well as FLS2 endocytosis [108]. The Arabidopsis PUB13, a close ortholog of rice SPOTTED LEAF 11 (SPL11), is furthermore known to regulate cell death, defence and flowering time in a SA-dependent manner $[109,110]$, as well as ubiquitinates LYSIN MOTIF RECEPTOR KINASE5 (LYK5) in vitro to regulate the turnover thereof [111]. The tomato (Solanum lycopersicum) homolog of PUB13, SIPUB13, on the other hand, works with group III members of ubiquitin-conjugating enzyme (E2s) to ubiquitinate FLS2 in vitro [112]. Negative regulation of MTI upon induction by several MAMPs has also been reported for the Arabidopsis E3 ubiquitin ligase triplets, PUB22, PUB23, and PUB24 respectively. Upon induction by MAMPs, including flg22 and chitin, pub22/pub23/pub24 triple mutants displayed an increased ROS burst and strong upregulation of OXI1 and WRKY29 defence genes [113].

Conclusively, as an outcome of recent fundamental studies, results have shown that immune receptors can potentially be transferred or engineered to enhance MAMP and/or pathogen recognition, and quantitative responsiveness, to control plant diseases in crop [33,100,114,115].

\section{Well-Studied MAMP Perception System(s)}

\subsection{Bacterial MAMPs}

\subsubsection{Flagellin Perception}

Flagellin is the main protein component of bacterial flagella, that acts as a MAMP in both plants and animals. Plants have a notably sensitive perception system for the highly conserved domain in the N-terminus of eubacterial flagellin [13]. The perception thereof, and particularly the N-terminus flagellin peptides, flg22 and flg15 from Pseudomonas syringae pv. tabaci, lead to the alkalinisation of the culture medium in suspension-cultured cells of Lycopersicon peruvianum (a wild relative of tomato), $A$. thaliana, potato and tobacco respectively [13]. Flagellin from the rice-incompatible strain, N1141 of $P$. avenae, was also shown to induce the hypersensitive cell death and accumulation of EL2 mRNA (elicitor-responsive gene) in cultured rice cells [116]. As mentioned, FLS2 is a LRR-RLK involved in the perception of the bacterial flagellin and immune responses in A. thaliana [76,96]. Furthermore, the recognition of bacterial flg22 by Arabidopsis FLS2 induces a FLS2-BAK1 complex formation and triggers defence signalling [96,98]. By using chemical cross-linking and immunoprecipitation techniques, Chinchilla et al. [117] showed that the specificity of flagellin perception and immune 
responses is mediated by the binding of FLS2 to flg22 in A. thaliana. The fls2 mutants carrying T-DNA insertion in the flagellin receptor gene FLS2 were more susceptible to Pst DC3000 compared to the wildtype (WT) [118]. Upon flg22 treatment, FLS2 mutants (fls2-101), generated by the insertion of T-DNA at the third FLS2 exon, showed impaired binding of the flg22 and reduced seedling growth inhibition [81].

As stated, flg22 induces a FLS2-BAK1 complex in a ligand-dependent manner, and leads to defence responses in A. thaliana [96]. This study showed that although BAK1 mutants (bak1-3 and bak1-4 with T-DNA inserted in $5^{\text {th }}$ intron and $9^{\text {th }}$ exon, respectively) were defective in an oxidative burst generation, they did not affect the binding of flg22 to FLS2. Furthermore, flg22 induces recruitment of the U-box E3 ubiquitin ligases (PUB12 and PUB13), previously mentioned, to the FLS2-BAK1 complex and this causes FLS2 degradation and the concomitant attenuation of immune signalling in Arabidopsis [107]. Here, there was a decrease in FLS2 ubiquitination and Pst DC3000 infection in mutant plants (pub12-2, pub13 and pub12/13 double knockout), compared to WT controls. A recent study has furthermore shown that flagellin-sensing 3 (FLS3) directly and specifically binds flgII-28 (a second flagellin epitope distinct from flg22), which enhances immune responses in tomato [85]. Finally, it is also important to note that BAK1 is involved in the defence signalling activities of both FLS2 and FLS3 $[85,96]$.

\subsubsection{EF-Tu Perception}

Elongation factor-thermo unstable (EF-Tu), a prokaryotic elongation factor involved in the synthesis of proteins, is a bacterial MAMP that is recognised by the LRR-RLK, EFR, in Arabidopsis [14]. $N$. benthamiana normally lacks EF-Tu responsiveness, but achieved the ability to recognise the MAMP when EFR was transiently expressed in the plant [14]. Kunze et al. [119] showed that EFR binds directly to the acetylated N-terminus epitope of elf18 (the first amino acids of EF-Tu) and elicits innate immunity in Arabidopsis and other Brassicaceae species. The first acetylated $12 \mathrm{~N}$-terminal amino acids (elf12) were, however, not able to elicit an immune response, but rather acted as a specific antagonist of elf18 [119]. Interestingly, even though EF-Tu induces MTI in rice, the elf18 peptide failed to trigger an immune response. However, another epitope, EFa50 (50-amino acid from central region of EF-Tu comprising Lys176 to Gly222) induced MTI responses, although the related PRR is still unknown [120]. Rice leaves treated with EFa50 induced early defence responses such as increased $\mathrm{H}_{2} \mathrm{O}_{2}$ and callose deposition, and triggered resistance to coinfection with pathogenic bacteria. In this regard, Arabidopsis EFR T-DNA insertion mutants (efr-1 and efr-2), with both T-DNAs inserted in $1^{\text {st }}$ exon, were insensitive to EF-Tu and susceptible to the bacterium Agrobacterium tumefaciens [14] (Table 1). In fact, efr mutants did not show typical growth inhibition as for the WT, increased oxidative burst and ethylene biosynthesis or induced resistance to Pst DC3000 upon EF-Tu treatment. Jeworutzki et al. [121] reported involvement of EFR and FLS2 in the $\mathrm{Ca}^{2+}$-associated opening of plasma membrane anion channels during early bacterial flagellin and EF-Tu defence signalling in Arabidopsis mesophyll cells. Using electrophysiological approaches, they showed that the efr-1 was defective in the membrane potential depolarisation, which is indispensable for cytosolic calcium influx in response to elf18 treatment.

\subsubsection{LPS Perception}

LPS is an amphipathic molecule found on the outer membrane of Gram-negative bacteria and protects the organism against antimicrobial compounds found in the environment $[23,122]$. This MAMP is involved in the bacterial adhesion and induction of defence-related responses in both mammals and plants [123]. In the former, LPS recognition is orchestrated by lipopolysaccharide binding protein (LBP), before recruitment into a complex comprising soluble myeloid differentiation protein 2 (MD-2), membrane attached cluster of differentiation 14 (CD14), and the transmembrane Toll-like receptor 4 (TLR4), thereby leading to mammalian defence activation against LPS [6,124]. LBP and bactericidal/permeability-increasing protein (BPI) thus play a vital role in regulation of immune responses against LPS in mammals [124,125]. As such, the mechanism by which LPS is recognised 
has been well-studied in animals, however, in plants, the mechanism of perception and recognised moiety/epitope(s) of LPS is still debateable.

In this regard, LPS, as well as its lipid A moiety from Burkholderia cepacia, Xanthomonas campestris and P. syringae, trigger the upregulation of genes involved in immunity and defence [126-128], with lipid A speculated to be the major elicitor in A. thaliana [129]. LPS has furthermore been shown to trigger defence responses, such as the generation of nitrogen oxide (NO), ROS, elevation of cytoplasmic $\mathrm{Ca}^{2+}$ concentration, stomatal closure and the expression of pathogenesis-related (PR) genes in Arabidopsis, tobacco and rice suspension cells [92,130-133]. Ranf et al. [92] earlier reported that LPS from Xanthomonas and Pseudomonas are sensed by the bulb-type (B-type) lectin S-domain (SD)-1 RLK lipooligosaccharide-specific reduced elicitation (LORE) and that LORE mutants showed defects in the LPS-induced elevation of cytosolic calcium, ROS and defence gene (AtFRK1) expression. Additionally, Shang-Guan et al. [129] reported the existence of two ROS production phases, characterised by a weak initial and second stronger ROS generation in A. thaliana. T-DNA insertion LORE mutants, however, showed little or no difference in second phase ROS production compared with WT, suggesting another LPS receptor(s). In contradiction to the original LORE study, a recent report implicated bacterial 3-hydroxy fatty acids in LORE-dependent induction of immune response in Arabidopsis [93]. Here, LORE could not sense LPS that was repurified to remove free 3-hydroxy fatty acids, indicating that LORE is not the receptor for LPS.

Using B. cepacia LPS-affinity capture strategies, Vilakazi et al. [134] and Baloyi et al. [135] identified BAK1 and other defence response proteins associated with the plasma membrane fraction in LPS-treated A. thaliana. Additionally, Arabidopsis LBP/BPI related-1 (AtLBR-1) and LBP/BPI related-2 (AtLBR-2) were shown to bind to both rough and smooth LPS, and regulate the expression of the pathogenesis-related 1 (PR1) gene [128]. AtLBR T-DNA single mutants (Atlbr-1, Atlbr-2-1, Atlbr2-2) and (Atlbr-DKO) double-knockouts, generated by crossing Atlbr-1 and Atlbr-2-1 plants, were defective in ROS generation and in upregulation of LPS-induced PR1 expression. A transcriptome analysis revealed that AtLBR-2 plays an indispensable role in the upregulation of 65 genes associated with defence responses upon Pseudomonas LPS treatment [136]. Furthermore, there was a defect in the upregulation of defence-related genes and salicylic acid (SA)-mediated signalling in the Atlbr-2-1 mutants, compared to the WT after Pseudomonas LPS treatment.

Lastly, a recent study has reported OsCERK1, the chitin co-receptor, as an LPS receptor/co-receptor in rice, but not in A. thaliana [137]. This indicates a significant difference between LPS perception in rice and Arabidopsis.

\subsubsection{Peptidoglycan Perception}

Rice chitin elicitor-binding protein (CEBiP) homologs in Arabidopsis, LYM1 and LYM3 RLPs, bind in a ligand-specific manner to PGNs, heteropolymers that are part of the building blocks of the cell walls of Gram-negative and Gram-positive bacteria [87]. There was a significant expression of the immune marker gene, flagellin-induced receptor kinase FRK1, upon treatment of Arabidopsis with PGNs from Gram-negative Pst DC3000 [87]. Homozygous T-DNA insertional mutants of LYM1 and LYM3 showed a strongly reduced PGN-inducible marker gene expression and were more susceptible to Pst DC3000 bacterial infection than the WT (Table 1). The same authors further reported the involvement of AtCERK1 in the LYM1/LYM3 perception of PGN and subsequent immune response in A. thaliana. Thus, AtCERK1 is the additional protein that provides the cytoplasmic kinase domain that is lacking in the LYM1/LYM3 RLPs needed for the downstream transphosphorylation of PGN signalling. The study suggests that Arabidopsis senses PGNs in a LYM1/LYM3 and AtCERK1-dependent manner, similar to the chitin perception system in rice that uses OsCEBiP and OsCERK1 [79]. Furthermore, the direct interaction of PGN with AtLYM1 and AtLYM3 has been reported, but not with AtCERK1 [87]. In rice, OsCERK1 associates with LysM motif-containing proteins (LYP4 and LYP6) in PGN-induced defence responses $[80,91,138]$. Importantly, the putative ability of CERK1 to participate in the recognition and signalling of more than one MAMP supports the hypothesis of the capability of one PRR/co-receptor 
to recognise more than one MAMP, which favours the generation of transgenic crop plants with enhanced/altered recognition capabilities [8].

\subsection{Fungal MAMPs}

\section{Chitin Perception}

Chitin is a $\beta(1 \rightarrow 4)$-linked polymer of $\mathrm{N}$-acetylglucosamine, a major structural component in the exoskeleton of arthropods and cell walls of fungi [21]. Chitin and its fragments (chitooligosaccharides) are MAMPs recognised by plants PRRs, which elicit defence responses such as the oxidative burst, protein phosphorylation, transcriptional activation of defence-related genes and phytoalexin biosynthesis $[21,78,139]$. Kaku et al. [78] isolated and characterised a chitin elicitor binding protein (OsCEBiP), an RLP involved in the perception of chitin oligosaccharides in cultured rice cells. It was observed that OsCEBiP has two LysM motifs and a C-terminal transmembrane domain, however no intracellular kinase domain, suggesting that it requires additional protein-partner(s) to perform a signal transduction role. In rice, the LysM receptor, OsCEBiP, binds to the chitin oligosaccharide and forms a complex with OsCERK1 to trigger defence response [79]. Conversely, in A. thaliana, the LysM receptor, AtCERK1, directly binds to chitin, dimerises and triggers immune responses [140]. In the extracellular domain, OsCERK1 has one LysM motif, whereas AtCERK1 has three LysM motifs [15,79] that mediate the binding of chitin [141,142]. There are five genes encoding LysM receptor-like kinases (LYKs), which are comprised of LYK1 (CERK1) and LYK2 - LYK5, and three genes encoding LysM receptor-like proteins (LYPs) in the A. thaliana genome [143]. In this regard, LysM receptor-like kinase 1 (LysM RLK1) is involved in chitin signalling and fungal resistance in Arabidopsis [144]. A T-DNA insertion knockout mutant of LysM RLK1 blocked the induction of chitooligosaccharide-responsive genes (CRGs) by chitooligosaccharides and increased susceptibility to fungal pathogens, but not bacterial pathogens. This was reversed when the mutant was complemented with the WT LysM RLK1 gene using the cauliflower mosaic virus (CaMV) 35 S promoter [15,144]. CERK1 KO mutants were unable to respond to chitin oligosaccharide elicitors when compared to the WT that exhibited rapid generation of ROS in Arabidopsis [15].

LYK4 is another LysM-RLK involved in chitin signalling and plant immunity in A. thaliana, and possibly in the chitin recognition receptor complex [89]. LYK4 mutants were defective in the activation of chitin-responsive genes and were also susceptible to bacterial and fungal pathogen infection. Cao et al. [90] showed that AtLYK5 binds chitin with higher affinity and forms a chitin-induced complex with AtCERK1, thereby triggering immunity in A. thaliana. The higher affinity of AtLYK5 for chitin, compared to AtCERK1, also suggests the former to be the major chitin binding protein in Arabidopsis. These authors [90] further reported involvement of AtLYK5 in chitin-induced AtCERK1 phosphorylation and homodimerisation [90]. While Atlyk5-2 was significantly impaired in chitin signal responses, Atlyk4/Atlyk5-2 double mutant resulted in a complete loss of chitin response, indicating an overlap of signal function between AtLYK5 and AtLYK4.

The LysM domain-containing glycosylphosphatidylinositol-anchored protein 2 (LYM2), one of the three CEBiP homologs in Arabidopsis, binds chitin and mediates a reduction in molecular flux via the plasmodesmata [88]. AtCERK1 is not involved in the chitin-mediated regulation of plasmodesmata flux, thereby suggesting the presence of an alternative novel disease resistance mechanism in Arabidopsis [88,145]. Shinya et al. [146] showed that the Arabidopsis LYM2 can recognise chitin oligosaccharides in a similar way as the rice OsCEBiP, but does not participate in chitin signalling. The KO mutant of LYM2 (lym2-1) was shown to be incapable of chitin-induced plasmodesmata flux, and susceptible to fungal pathogens (Botrytis cenerea and Alternaria brassicicola), but exhibited chitin-induced MAPK activation and an oxidative burst when compared to the WT [88,146]. LysM RLK1-interacting kinase 1 (LIK1) interacts with CERK1 and regulates chitin-induced MTI in Arabidopsis [147]. LIK1 mutants (lik1-1, lik1-2, lik1-3 and lik1-4), with T-DNA insertions located in intron 2, 13, and exon 18, respectively, showed an enhanced response to both chitin and flagellin 
elicitors. Furthermore, the mutants were defective in the expression of genes involved in jasmonic acid (JA) and ethylene (ET) signalling pathways, that have been shown to mediate resistance to necrotrophic pathogens [148]. In A. thaliana a powdery mildew-resistant kinase 1 (PMRK1), a RLK that is localised in the plasma membrane, is responsible for early chitin-induced defence signals against fungal pathogens [149]. PMRK1 KO mutant (pmrk1) was more susceptible to both Golovinomyces cichoracearum and Plectosphaerella cucumerina (Table 1). In fact, these numerous identified PPRs linked to chitin perception suggest the complexity of plant chitin defence signalling.

Table 1. Defence-related PRRs and associated protein KOs in A. thaliana.

\begin{tabular}{|c|c|c|c|c|c|}
\hline $\begin{array}{l}\text { Receptors/Associated } \\
\text { Proteins }\end{array}$ & $\begin{array}{l}\text { Ectodomain } \\
\text { Motif * }\end{array}$ & Family & KO Line(s) & Function & References \\
\hline \multicolumn{6}{|l|}{ Bacterial MAMPs } \\
\hline FLS2 & ○ & RLK & $f l s 2, f l s 2-101$ & $\begin{array}{l}\text { Recognition of flagellin } \\
\text { (flg22 epitope) }\end{array}$ & {$[81,118]$} \\
\hline EFR & ○ & RLK & efr-1, efr-2 & $\begin{array}{l}\text { Recognition of EF-Tu } \\
\text { (elf18 epitope) }\end{array}$ & {$[14,121]$} \\
\hline LYM1 and LYM3 & & RLP & $\begin{array}{l}\text { lym1-1, lym1-2 } \\
\text { and lym3-1, } \\
\text { lym3-2 }\end{array}$ & Recognition of PGNs & [87] \\
\hline LBR-1 & NTD & BPI/LBP & $l b r-1$ & Recognition of LPS & [128] \\
\hline LBR-2 & NTD & BPI/LBP & $l b r-2-1, l b r-2-2$ & Recognition of LPS & {$[128,136]$} \\
\hline LORE & & RLK & lore & $\begin{array}{l}\text { Recognition of } \\
\text { mc-3-OH-FAs }\end{array}$ & {$[93,129]$} \\
\hline \multicolumn{6}{|l|}{ Fungal MAMPs } \\
\hline AtLYK1 (AtCERK1) & & RLK & $\begin{array}{l}\text { lyk1, cerk1-1, } \\
\quad \text { cerk1-2 }\end{array}$ & Recognition of chitin & {$[15,79,144,146]$} \\
\hline LYM2 & 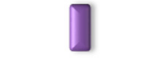 & RLP & $\operatorname{lym} 2-1$ & Recognition of chitin & {$[88,146]$} \\
\hline LYK4 &  & RLK & $\operatorname{lyk} 4$ & Recognition of chitin & [89] \\
\hline LYK5 & L & RLK & $\operatorname{lyk5-2}$ & Recognition of chitin & [90] \\
\hline LIK1 & 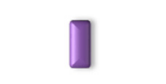 & RLK & $\begin{array}{l}\text { lik1-1, lik1-2, } \\
\text { lik1-3, lik1-4 }\end{array}$ & Interacts with CERK1 & [147] \\
\hline PMRK1 & NTD & RLK & PMRK1 & Recognition of chitin & [149] \\
\hline
\end{tabular}

* Coloured symbols as defined in Figure 3. NTD = N-terminal domain.

\section{BAK1 and Other Associated Proteins in MAMP Signalling}

Following MAMP perception, PRRs trigger downstream events involving protein association/dissociation. BAK1 was initially identified as a co-receptor in BRI1-mediated brassinosteroid (BR) signalling, which modulates plant growth and development $[150,151]$. Studies have shown that BAK1 and related somatic embryogenesis receptor kinases (SERK) proteins associate with other LRR-RLKs or LRR-RLPs, and regulate plant growth and immunity $[98,152,153]$.

Table 2 outlines different BAK1 and other associated proteins, and the implication of their KOs in plant MTI. In A. thaliana, both FLS2 and EFR form a complex with the co-receptor BAK1 to elicit immune responses immediately upon flg22 or elf18 perception, respectively $[96,98,99,154]$. Plants carrying BAK1 mutants (bak1-3 and bak1-4), generated by T-DNA insertion, displayed abnormal early and late flagellin-triggered responses [96,98]. In this regard, there was a significant reduction in the oxidative burst triggered by elf26 in $B A K 1$ mutants, indicating that EF-Tu is also affected by the mutation in BAK1 [96]. Interestingly, BAK1 mutants were not completely impaired to flg22 or elf18 perception, indicating that BAK1 was not the only rate-limiting component and therefore suggests additional regulatory protein(s), such as BKK1, that are part of the FLS2 and EFR receptor complexes [96,98,152]. BAK1-disrupted N. benthamiana plants displayed decreased induction of MTI responses by the csp22 peptide (part of bacterial cold-shock protein) and INF1 (an oomycete elicitor) [98]. Furthermore, Arabidopsis $B A K 1 \mathrm{KO}$ mutants exhibited increased susceptibility to necrotrophic fungal pathogens, such as Botrytis cinerea and Alternaria brassicicola [155]. These results suggest a central role for BAK1 
in modulating other PRRs besides FLS2 and EFR in plant defence signalling. The exact mechanism by which BAK1 mediates defence signalling is, however, not resolved. A recent study also showed BAK1 involvement in the tomato FLS3 recognition of flgII-28 (another flagellin epitope) and resulting immune response signalling [85].

BAK1 and BAK1-LIKE1 (BKK1) have dual physiological roles by positively regulating a BR-dependent plant growth pathway, and negatively regulating a BR-independent cell-death [156]. Here, cell death-control mediated by BAK1 and BKK1 is SA-dependent [157]. Upon flagellin perception, BIK1 as a RLCK, associates with the FLS2-BAK1 receptor complex to initiate plant innate immunity and cell death [28]. There was a significant loss of flg22-induced resistance to Pst DC3000 infection in BIK1 mutant seedlings, however, the mutation did not affect flg22-induced FLS2 and BAK1 association. On the other hand, BIK1 mutants were susceptible to necrotrophic pathogens but were resistant to a virulent bacterial pathogen Pst DC3000 [158]. Chen et al. [159] demonstrated that the bik1 mutant displayed a strong SA-dependent resistance to Plasmodiophora brassicae, an obligate biotroph protist that induces gall formation in cruciferous plants. Bak1-4 bik1 double mutants exhibited increased expression of plant defence genes and cell death phenotypes compared to BIK1 single mutant [72], highlighting the cooperativity of BIK1 and BAK1 influence in plant immunity.

Table 2. Defence-related BAK1 and other associated protein KOs in A. thaliana.

\begin{tabular}{|c|c|c|c|c|c|}
\hline Co-Receptor(s)/Proteins & $\begin{array}{l}\text { Ectodomain } \\
\text { Motifs * }\end{array}$ & Family & KO Line(s) & Function & References \\
\hline BAK1 & ○ & RLK & bak1-3, bak1-4 & Co-receptor for PRRs & {$[96,98,155]$} \\
\hline BIR1 & O & RLK & bir1-1 & $\begin{array}{l}\text { Suppresses cell death; } \\
\text { Negative regulator of } \\
\text { MTI }\end{array}$ & [120] \\
\hline SOBIR1 & ○ & RLK & sobir1-12 & $\begin{array}{l}\text { Adaptors/co-receptor } \\
\text { for LRR-RLPs, } \\
\text { activates immune } \\
\text { response }\end{array}$ & [160] \\
\hline BIR2 & ○ & RLK & bir2-1 & $\begin{array}{c}\text { Negative regulator of } \\
\text { MTI }\end{array}$ & [71] \\
\hline BIK1 & None & RLCK & $b i k 1$ & Modulator of MTI & {$[72,158,159]$} \\
\hline IOS1 & Malectin-like & RLK & ios1-2 & Scaffold for PRR & [103] \\
\hline BKK1 & ○ & RLK & $b k k 1$ & Regulator of cell death & [156] \\
\hline FER & Malectin-like & RLK & fer-4 & Scaffold for PRR & [105] \\
\hline
\end{tabular}

BIR2, a novel LRR-RLK, interacts with BAK1 in a kinase-dependent manner, and negatively regulates BAK1-dependent MAMP-triggered immune signalling [71]. Upon ligand binding to FLS2, BAK1 is released from BIR2 and recruited to the FLS2 complex. Therefore, BIR2 inhibits autoimmune cell-death responses by keeping BAK1 under control. Gao et al. [102] showed that BIR1, a BAK1-interacting RLK, negatively regulates multiple plant resistance signalling responses, and suppresses cell death in Arabidopsis. BIR1 KO mutants (bir1-1) showed activation of constitutive defence responses and extensive cell death. However, the LRR-RLK SUPPRESSOR OF BIR1-1 (SOBIR1) and BAK1 function as co-receptors for LRR-RLPs, BAK1, and not SOBIR1, acts a co-receptor for LRR-RLKs [154]. SOBIR1, a co-receptor/adaptor for LRR-RLPs recruits BAK1 to SOBIR1-RLP23 and SOBIR1-RLP30 complex upon nlp20 and Sclerotinia culture filtrate elicitor1 (SCFE1) perception, respectively, in Arabidopsis [17,160]. Here, SOBIR1 mutant (sobir1-12) was more susceptible to fungal Sclerotinia sclerotiorum and B. cineria [160]. The dissociation of BIR1 upon MAMP recognition by PRRs allows BAK1 to form an active complex with SOBIR1, which triggers downstream cell death and defence signalling [103].

The Arabidopsis malectin-like LRR-RLK, IMPAIRED OOMYCETE SUSCEPTIBILITY1 (IOS1) associated with PRRs FLS2, EFR and CERK1 in BAK1-dependent and -independent MTI responses [104]. 
Arabidopsis IOS1 mutant (ios1-2) showed perturbations in the latter, including defective chitin responses and delayed upregulation of the PTI marker gene FLG22-INDUCED RECEPTOR-LIKE KINASE1 (FRK1), as well as reduced downy mildew infection [103]. The malectin-like RLK FERONIA (FER), facilitates the ligand-induced complex formation of PRRs in Arabidopsis [105,161]. As such, the EFR/FLS2-BAK1 complex formation has been shown to be promoted by FER and inhibited by Rapid Alkalinization Factor 23 (RALF23) [105]. Furthermore, a FER mutant (fer-4) showed diminished ligand-induced EFR/FLS2 complex formation, with the co-receptor BAK1. In addition, AtFER is involved in the negative regulation of jasmonic acid (JA) and coronatine (COR) signalling [162]. In support, BAK1 and other defence-responsive proteins were identified in A. thaliana plasma membranes after B. cepacia and E. coli LPS treatments $[134,135]$. Here, proteins identified were similar to some previously implicated proteins upon flg22 elicitation, suggesting that LPS perception and signalling could likely resemble that of flg22.

\section{Conclusions and Future Perspectives}

MAMPs reveal the presence of pathogenic microbes, leading to the activation and upregulation of basal defence responses in plants. PRRs play a central role in MAMP recognition and the activation of downstream defence signalling. Several PRRs have been identified and classified, although the molecular mechanism(s) underlying perception of MAMPs in plants remains elusive in most cases. We have outlined several PRRs with their cognate MAMPs, and further presented the subsequent response perturbations in $\mathrm{KO}$ mutants, as well as those of BAK1 and other associated proteins. In addition, we reviewed the role that membrane raft domains play, in which PRRs have been suggested to be localised during the perception response, using flg22-mediated PRR-dependent ROS production in MTI as an example to set the stage for subsequent $\mathrm{KO}$ studies. From this review, it is clear that there is a need for more KO studies targeting the genes encoding other PRR, as well as co-receptor/associated proteins, to clearly unravel their roles in plant defence signalling. By comparing the phenotypes of wildtype (WT) and $\mathrm{KO}$ mutant lines, valuable information of a functional nature can be gained to support engineering of enhanced or new perception capabilities that would lead to an increase in quantitative immune responsiveness, ultimately in order to contribute towards amelioration of crop plant losses due to pathogen attack. As such, the review supports the notion that investigation of the PRR-co-receptor complex, as well as that involving other defence-associated proteins by $\mathrm{KO}$ studies, can enhance the understanding of MTI and the possible generation of pathogen-resistant crops.

$\begin{array}{ll}\text { Abbreviation } & \\ \text { BAK1 } & \text { Brassinosteroid insensitive 1 (BRI1) associated receptor kinase 1 } \\ \text { EFR } & \text { Elongation factor-thermo unstable receptor } \\ \text { ETI } & \text { Effector-triggered immunity } \\ \text { FLS2 } & \text { Flagellin-sensitive 2 } \\ \text { KO } & \text { Knockout } \\ \text { LPS } & \text { Lipopolysaccarides } \\ \text { LRR } & \text { Leucine-rich repeat } \\ \text { MAMP } & \text { Microbe-associated molecular pattern } \\ \text { MTI } & \text { MAMP-triggered immunity } \\ \text { PRR } & \text { Pattern recognition receptor } \\ \text { RLCK } & \text { Receptor-like cytoplasmic kinase } \\ \text { RLK } & \text { Receptor-like kinase } \\ \text { RLP } & \text { Receptor-like protein } \\ \text { T-DNA } & \text { Transfer DNA }\end{array}$

Author Contributions: L.A.P. and I.A.D. conceptualized the work; B.C.O. prepared the initial draft, and I.A.D. and L.A.P. critically revised the manuscript. All authors have read and agreed to the published version of the manuscript. 
Funding: L.A.P. would like to acknowledge financial support received South African National Research Foundation (NRF) grant no. 113313, and well as fellowship support to B.C.O.

Conflicts of Interest: The authors declare no conflict of interest.

\section{References}

1. Cerda, R.; Avelino, J.; Gary, C.; Tixier, P.; Lechevallier, E.; Allinne, C. Primary and secondary yield losses caused by pests and diseases: Assessment and modeling in coffee. PLoS ONE 2017, 12, 1-17. [CrossRef]

2. Figueroa, M.; Hammond-Kosack, K.E.; Solomon, P.S. A review of wheat diseases-a field perspective. Mol. Plant Pathol. 2018, 19, 1523-1536. [CrossRef]

3. Uppalapati, S.R.; Ishiga, Y.; Wangdi, T.; Urbanczyk-wochniak, E.; Ishiga, T.; Mysore, K.S.; Bender, C.L. Pathogenicity of Pseudomonas syringae pv. tomato on Tomato seedlings: Phenotypic and gene expression analyses of the virulence function of coronatine. MPMI 2008, 21, 383-395. [CrossRef]

4. Dean, R.; Van Kan, J.A.L.; Pretorius, Z.A.; Hammond-Kosack, K.E.; Pietro, A.D.; Spanu, P.D.; Rudd, J.J.; Dickman, M.; Kahmann, R.; Ellis, J.; et al. The Top 10 fungal pathogens in molecular plant pathology. Mol. Plant Pathol. 2012, 13, 414-430. [CrossRef]

5. Derevnina, L.; Petre, B.; Kellner, R.; Dagdas, Y.F.; Sarowar, M.N.; Giannakopoulou, A.; Carlos, J.; Concepcion, D.; Chaparro-garcia, A.; Pennington, H.G.; et al. Emerging oomycete threats to plants and animals. Philos. Trans. R. Soc. 2016, 371, 20150459. [CrossRef]

6. Nürnberger, T.; Kemmerling, B.; Piater, L. Innate immunity in plants and animals: Striking similarities and obvious differences. Immunol. Rev. 2004, 198, 249-266. [CrossRef]

7. Kumar, H.; Kawai, T.; Akira, S. Pathogen recognition by the innate immune system. Int. Rev. Immunol. 2011, 30, 16-34. [CrossRef]

8. Zipfel, C. Plant pattern-recognition receptors. Trends Immunol. 2014, 35, 345-351. [CrossRef]

9. Ranf, S. Pattern recognition receptors-versatile genetic tools for engineering broad-spectrum disease resistance in crops. Agronomy 2018, 8, 134. [CrossRef]

10. Sanabria, N.M.; Huang, J.C.; Dubery, I.A. Self/nonself perception in plants in innate immunity and defense. Self/Nonself 2010, 1, 40-54. [CrossRef]

11. Dubery, I.A.; Sanabria, N.M.; Huang, J.C. Nonself perception in plant innate immunity. Adv. Exp. Med. Biol. 2012, 738, 79-107. [CrossRef]

12. Ranf, S. Sensing of molecular patterns through cell surface immune receptors. Curr. Opin. Plant Biol. 2017, 38, 68-77. [CrossRef] [PubMed]

13. Felix, G.; Duran, J.D.; Volko, S.; Boller, T. Plants have a sensitive perception system for the most conserved domain of bacterial flagellin. Plant J. 1999, 18, 265-276. [CrossRef] [PubMed]

14. Zipfel, C.; Kunze, G.; Chinchilla, D.; Caniard, A.; Jones, J.D.G.; Boller, T.; Felix, G. Perception of the bacterial PAMP EF-Tu by the receptor EFR restricts Agrobacterium-mediated transformation. Cell 2006, 125, 749-760. [CrossRef]

15. Miya, A.; Albert, P.; Shinya, T.; Desaki, Y.; Ichimura, K.; Shirasu, K.; Narusaka, Y.; Kawakami, N.; Kaku, H.; Shibuya, N. CERK1, a LysM receptor kinase, is essential for chitin elicitor signaling in Arabidopsis. PNAS 2007, 104, 1-6. [CrossRef]

16. Boutrot, F.; Zipfel, C. Function, discovery, and exploitation of plant pattern recognition receptors for broad-spectrum disease resistance. Annu. Rev. Phytopathol. 2017, 55, 257-286. [CrossRef]

17. Albert, I.; Böhm, H.; Albert, M.; Feiler, C.E.; Imkampe, J.; Wallmeroth, N.; Brancato, C.; Raaymakers, T.M.; Oome, S.; Zhang, H.; et al. NLP-triggered immunity. Nat. Plants 2015, 1, 1-9. [CrossRef]

18. Klarzynski, O.; Plesse, B.; Joubert, J.; Yvin, J.; Kopp, M.; Kloareg, B.; Fritig, B. Linear $\beta$-1, 3 glucans are elicitors of defense responses in tobacco. Plant Physiol. 2000, 124, 1027-1038. [CrossRef]

19. Felix, G.; Boller, T. Molecular sensing of bacteria in plants: The highly conserved RNA-binding motif RNP-1 of bacterial cold shock proteins is recognized as an elicitor signal in tobacco. J. Biol. Chem. 2003, 278, 6201-6208. [CrossRef] [PubMed]

20. Ron, M.; Avni, A. The receptor for the fungal elicitor ethylene-inducing xylanase is a member of a resistance-like gene family in tomato. Plant Cell 2004, 16, 1604-1615. [CrossRef]

21. Knogge, W.; Scheel, D. LysM receptors recognize friend and foe. PNAS 2006, 103, 10829-10830. [CrossRef] [PubMed] 
22. Laquitaine, L.; Gomès, E.; François, J.; Marchive, C.; Pascal, S.; Hamdi, S.; Atanassova, R.; Delrot, S.; Coutos-thévenot, P. Molecular basis of ergosterol-induced protection of grape against Botrytis cinerea: Induction of type I LTP promoter activity, WRKY, and stilbene synthase gene expression. MPMI 2006, 19, 1103-1112. [CrossRef] [PubMed]

23. Silipo, A.; Erbs, G.; Shinya, T.; Maxwell, J.; Parrilli, M.; Lanzetta, R. Glycoconjugates as elicitors or suppressors of plant innate immunity. Glycobiology 2010, 20, 406-419. [CrossRef] [PubMed]

24. Klemptner, R.L.; Sherwood, J.S.; Tugizimana, F.; Dubery, I.A.N.A.; Piater, L.A. Ergosterol, an orphan fungal microbe-associated molecular pattern (MAMP). Mol. Plant Pathol. 2014, 15, 747-761. [CrossRef]

25. Macho, A.P.; Zipfel, C. Plant PRRs and the activation of innate immune signaling. Mol. Cell 2014, 54, $263-272$. [CrossRef] [PubMed]

26. Kadota, Y.; Shirasu, K.; Zipfel, C. Regulation of the NADPH oxidase RBOHD during plant immunity. Plant Cell Physiol. 2015, 56, 1472-1480. [CrossRef]

27. Torres, M.A.; Dangl, J.L.; Jones, J.D.G. Arabidopsis gp91 phox homologues AtrbohD and AtrbohF are required for accumulation of reactive oxygen intermediates in the plant defense response. PNAS 2002, 99, 517-522. [CrossRef]

28. Lu, D.; Wu, S.; Gao, X.; Zhang, Y.; Shan, L.; He, P. A receptor-like cytoplasmic kinase, BIK1, associates with a flagellin receptor complex to initiate plant innate immunity. PNAS 2010, 107, 496-501. [CrossRef]

29. Jones, J.D.G.; Dangl, J.L. The plant immune system. Nature 2006, 444, 323-329. [CrossRef]

30. Van Loon, L.C.; Rep, M.; Pieterse, C.M.J. Significance of inducible defense-related proteins in infected plants. Annu. Rev. Phytopathol. 2006, 44, 135-162. [CrossRef]

31. De Wit, P.J.G.M. How plants recognize pathogens and defend themselves. Cell. Mol. Life Sci. 2007, 64, 2726-2732. [CrossRef] [PubMed]

32. Peng, Y.; Van Wersch, R.; Zhang, Y. Convergent and divergent signaling in PAMP-triggered immunity and effector-triggered immunity. MPMI 2018, 31, 403-409. [CrossRef] [PubMed]

33. Boller, T. Experimental evidence of a role for RLKs in innate immunity. In Receptor-Like Kinases in Plants: From Development to Defense; Tax, F., Kemmerling, B., Eds.; Springer: Berlin, Germany, 2002; pp. 67-77.

34. Lu, D.; He, P.; Shan, L. Bacterial effectors target BAK1-associated receptor complexes: One stone two birds. Commun. Integr. Biol. 2010, 3, 80-83. [CrossRef]

35. Vidhyasekaran, P. Switching on Plant Innate Immunity Signaling System: Bioengineering and Molecular Manipulation of PAMP-PIMP-PRR Signaling Complex; Springer International Publishing: Cham, Switzerland, 2016; pp. 1-25.

36. Tang, D.; Wang, G.; Zhou, J.M. Receptor kinases in plant-pathogen interactions: More than pattern recognition. Plant Cell 2017, 29, 618-637. [CrossRef]

37. Saijo, Y.; Loo, E.P.; Yasuda, S. Pattern recognition receptors and signaling in plant-Microbe interactions. Plant J. 2018, 93, 592-613. [CrossRef]

38. O'Malley, R.C.; Barragan, C.C.; Ecker, J.R. A user's guide to the Arabidopsis T-DNA insertional mutant collections. Methods Mol Biol. 2015, 1284, 323-342. [CrossRef]

39. Krysan, P.J.; Young, J.C.; Sussman, M.R. T-DNA as an insertional mutagen in Arabidopsis. Plant Cell 1999, 11, 2283-2290. [CrossRef]

40. Initiative, T.A.G. Analysis of the genome sequence of the flowering plant Arabidopsis thaliana. Nature 2000, 408, 796-815. [CrossRef]

41. Thorneycroft, D.; Sherson, S.M.; Smith, S.M. Using gene knockouts to investigate plant metabolism. J. Exp. Bot. 2001, 52, 1593-1601. [CrossRef]

42. Agrawal, N.; Dasaradhi, P.V.N.; Mohmmed, A.; Malhotra, P.; Bhatnagar, R.K.; Mukherjee, S.K. RNA interference: Biology, mechanism, and application. Microbiol. Mol. Biol. Rev. 2003, 67, 657-685. [CrossRef]

43. Zhang, F.; Maeder, M.L.; Unger-wallace, E.; Hoshaw, J.P.; Reyon, D.; Christian, M. High frequency targeted mutagenesis in Arabidopsis thaliana using zinc finger nucleases. PNAS 2010, 107, 12028-12033. [CrossRef] [PubMed]

44. Li, T.; Spalding, M.; Weeks, D.P.; Yang, B. High-efficiency TALEN-based gene editing produces disease-resistant rice. Nat. Biotechnol. 2012, 30, 390-392. [CrossRef] [PubMed]

45. Jankele, R.; Svoboda, P. TAL effectors: Tools for DNA targeting. Brief. Funct. Genom. 2014, 13, 409-419. [CrossRef] [PubMed] 
46. Borrelli, V.M.G.; Brambilla, V.; Rogowsky, P.; Marocco, A.; Lanubile, A. The enhancement of plant disease resistance using CRISPR/Cas9 technology. Front. Plant Sci. 2018, 9, 1245. [CrossRef] [PubMed]

47. Das, A.; Sharma, N.; Prasad, M. CRISPR/Cas9: A novel weapon in the arsenal to combat plant diseases. Front. Plant Sci. 2019, 9, 2008. [CrossRef]

48. Kawakami, K.; Largaespada, D.A.; Ivics, Z. Transposons as tools for functional genomics in vertebrate models. Trends Genet. 2017, 33, 784-801. [CrossRef]

49. An, G.; Lee, S.; Kim, S.H.; Kim, S.R. Molecular genetics using T-DNA in rice. Plant Cell Physiol. 2005, 46, 14-22. [CrossRef]

50. Radhamony, R.N. T-DNA insertional mutagenesis in Arabidopsis: A tool for functional genomics. Electron. J. Biotechnol. 2005, 8, 82-106. [CrossRef]

51. Gelvin, S.B. Agrobacterium-mediated plant transformation: The biology behind the "gene-jockeying" tool. Microbiol. Mol. Biol. Rev. 2003, 67, 16-37. [CrossRef]

52. Ram, H.; Soni, P.; Salvi, P.; Gandass, N.; Sharma, A.; Kaur, A.; Sharma, T.R. Insertional mutagenesis approaches and their use in rice for functional genomics. Plants 2019, 8, 310. [CrossRef]

53. Tzfira, T.; Li, J.; Lacroix, B.; Citovsky, V. Agrobacterium T-DNA integration: Molecules and models. Trends Genet. 2004, 20, 375-383. [CrossRef] [PubMed]

54. Jupe, F.; Rivkin, A.C.; Michael, T.P.; Zander, M.; Motley, S.T.; Sandoval, J.P.; Keith Slotkin, R.; Chen, H.; Castanon, R.; Nery, J.R.; et al. The complex architecture and epigenomic impact of plant T-DNA insertions. PLoS Genet. 2019, 15, e1007819. [CrossRef] [PubMed]

55. Nacry, P.; Camilleri, C.; Courtial, B.; Caboche, M.; Bouchez, D. Major chromosomal rearrangements induced by T-DNA transformation in Arabidopsis. Genetics 1998, 149, 641-650. [PubMed]

56. Tamura, K.; Kawabayashi, T.; Shikanai, T.; Hara-Nishimura, I. Decreased expression of a gene caused by a T-DNA insertion in an adjacent gene in arabidopsis. PLoS ONE 2016, 11, 1-10. [CrossRef]

57. Sanger, S.J.; Nicolson, G.L. The fluid mosaic model of the structure of cell membranes. Science 1972, 175, 720-731. [CrossRef]

58. Simons, K.; Ikonen, E. Functional rafts in cell membranes. Nature 1997, 387, 569-572. [CrossRef]

59. Pike, L.J. Rafts defined: A report on the keystone symposium on lipid rafts and cell function. J. Lipid Res. 2006, 47, 1597-1598. [CrossRef]

60. Bieberich, E. Sphingolipids and lipid rafts: Novel concepts and methods of analysis. Chem. Phys. Lipids 2018, 216, 114-131. [CrossRef]

61. Simons, K.; Gerl, M.J. Revitalizing membrane rafts: New tools and insights. Nat. Rev. Mol. Cell Biol. 2010, 11, 688-699. [CrossRef]

62. Simons, K.; Sampaio, J.L. Membrane organization and lipid rafts. Cold Spring Harb. Perspect. Biol. 2011, 1-17. [CrossRef]

63. Zappel, N.F.; Panstruga, R. Heterogeneity and lateral compartmentalization of plant plasma membranes. Curr. Opin. Plant Biol. 2008, 11, 632-640. [CrossRef] [PubMed]

64. Cacas, J.; Furt, F.; Le, M.; Schmitter, J.; Buré, C.; Gerbeau-pissot, P.; Moreau, P.; Bessoule, J.; Simon-Plas, F.; Mongrand, S. Lipids of plant membrane rafts. Prog. Lipid Res. 2012, 51, 272-299. [CrossRef] [PubMed]

65. Simon-Plas, F.; Perraki, A.; Bayer, E.; Gerbeau-Pissot, P.; Mongrand, S. An update on plant membrane rafts. Curr. Opin. Plant Biol. 2011, 14, 642-649. [CrossRef] [PubMed]

66. Burkart, R.C.; Stahl, Y. Dynamic complexity: Plant receptor complexes at the plasma membrane. Curr. Opin. Plant Biol. 2017, 40, 15-21. [CrossRef]

67. Kierszniowska, S.; Seiwert, B.; Schulze, W.X. Definition of Kaul sterol-rich membrane microdomains by differential treatment with methyl- $\beta$-cycledextrin and quantitative proteomics. Mol. Cell. Proteom. 2009, 8, 612-623. [CrossRef]

68. Fujiwara, M.; Hamada, S.; Hiratsuka, M.; Fukao, Y.; Kawasaki, T.; Rop, R. Proteome analysis of detergent-resistant membranes (DRMs) associated with OsRac1-mediated innate immunity in rice. Plant Cell Physiol. 2009, 50, 1191-1200. [CrossRef]

69. Stanislas, T.; Bouyssie, D.; Rossignol, M.; Vesa, S. Quantitative proteomics reveals a dynamic association of proteins to detergent-resistant membranes upon elicitor signaling in tobacco. Mol. Cell. Proteom. 2009, 8, 2186-2198. [CrossRef] 
70. Keinath, N.F.; Kierszniowska, S.; Lorek, J.; Bourdais, G.; Kessler, S.A.; Shimosato-asano, H.; Grossniklaus, U.; Schulze, W.X.; Robatzek, S.; Panstruga, R. PAMP (Pathogen-associated Molecular Pattern) -induced changes in plasma membrane compartmentalization reveal novel components of plant immunity. J. Biol. Chem. 2010, 285, 39140-39149. [CrossRef]

71. Halter, T.; Imkampe, J.; Mazzotta, S.; Wierzba, M.; Postel, S.; Bücherl, C.; Kiefer, C.; Stahl, M.; Chinchilla, D.; Wang, X.; et al. The leucine-rich repeat receptor kinase BIR2 is a negative regulator of BAK1 in plant immunity. Curr. Biol. 2014, 24, 134-143. [CrossRef]

72. Liu, J.; Chen, S.; Chen, L.; Zhou, Q.; Wang, M.; Feng, D.; Li, J.F.; Wang, J.; Wang, H.B.; Liu, B. BIK1 cooperates with BAK1 to regulate constitutive immunity and cell death in Arabidopsis. J. Integr. Plant Biol. 2017, 59, 234-239. [CrossRef]

73. Yadeta, K.A.; Elmore, J.M.; Coaker, G. Advancements in the analysis of the Arabidopsis plasma membrane proteome. Front. Plant Sci. 2013, 4, 1-10. [CrossRef] [PubMed]

74. Wan, W.L.; Zhang, L.; Pruitt, R.; Zaidem, M.; Brugman, R.; Ma, X.; Krol, E.; Perraki, A.; Kilian, J.; Grossmann, G.; et al. Comparing Arabidopsis receptor kinase and receptor protein-mediated immune signaling reveals BIK1-dependent differences. New Phytol. 2019, 221, 2080-2095. [CrossRef] [PubMed]

75. Morel, J.; Claverol, S.; Mongrand, S.; Furt, F.; Fromentin, J.; Bessoule, J.; Blein, J.; Simon-Plas, F. Proteomics of plant detergent-resistant membranes. Mol. Cell. Proteomics 2006, 5, 1396-1411. [CrossRef] [PubMed]

76. Gómez-Gómez, L.; Boller, T. FLS2: An LRR Receptor-like kinase involved in the perception of the bacterial elicitor flagellin in Arabidopsis. Mol. Cell 2000, 5, 1003-1011. [CrossRef]

77. Gómez-Gómez, L.; Boller, T. Flagellin perception: A paradigm for innate immunity. Trends Plant Sci. 2002, 7, 251-256. [CrossRef]

78. Kaku, H.; Nishizawa, Y.; Ishii-Minami, N.; Akimoto-Tomiyama, A.; Dohmae, N.; Takio, K.; Minami, E.; Shibuya, N. Plant cells recognize chitin fragments for defence signaling through a plasma membrane receptor. PNAS 2006, 103, 11086-11091. [CrossRef]

79. Shimizu, T.; Nakano, T.; Takamizawa, D.; Desaki, Y.; Ishii-Minami, N.; Nishizawa, Y. Two LysM receptor molecules, CEBiP and OsCERK1, cooperatively regulate chitin elicitor signaling in rice. Plant J. 2010, 64, 204-214. [CrossRef]

80. Desaki, Y.; Miyata, K.; Suzuki, M.; Shibuya, N.; Kaku, H. Plant immunity and symbiosis signaling mediated by LysM receptors. Innate Immun. 2018, 24, 92-100. [CrossRef]

81. Dunning, F.M.; Sun, W.; Jansen, K.L.; Helft, L.; Bent, A.F. Identification and mutational analysis of Arabidopsis FLS2 leucine-rich repeat domain residues that contribute to flagellin perception. Plant Cell 2007, 19, 3297-3313. [CrossRef]

82. Saur, I.M.L.; Kadota, Y.; Sklenar, J.; Holton, N.J.; Smakowska, E.; Belkhadir, Y. NbCSPR underlies age-dependent immune responses to bacterial cold shock protein in Nicotiana benthamiana. PNAS 2016, 113, 3389-3394. [CrossRef]

83. Wang, L.; Albert, M.; Einig, E.; Fürst, U.; Krust, D.; Felix, G. The pattern-recognition receptor CORE of Solanaceae detects bacterial cold-shock protein. Nat. Plants 2016, 2, 16185. [CrossRef] [PubMed]

84. Pruitt, R.N.; Schwessinger, B.; Joe, A.; Thomas, N.; Liu, F.; Albert, M.; Robinson, M.R.; Chan, L.J.G.; Luu, D.D.; Chen, H.; et al. The rice immune receptor XA21 recognizes a tyrosine-sulfated protein from a Gram-negative bacterium. Sci. Adv. 2015, 1, e1500245. [CrossRef] [PubMed]

85. Hind, S.R.; Strickler, S.R.; Boyle, P.C.; Dunham, D.M.; Bao, Z.; Doherty, I.M.O.; Baccile, J.A.; Hoki, J.S.; Viox, E.G.; Clarke, C.R.; et al. Tomato receptor FLAGELLIN-SENSING 3 binds flgII-28 and activates the plant immune system. Nat. Plants 2016, 2,1-8. [CrossRef] [PubMed]

86. Du, J.; Verzaux, E.; Chaparro-Garcia, A.; Bijsterbosch, G.; Keizer, L.C.P.; Zhou, J.; Liebrand, T.W.H.; Xie, C.; Govers, F.; Robatzek, S.; et al. Elicitin recognition confers enhanced resistance to Phytophthora infestans in potato. Nat. Plants 2015, 1, 15034. [CrossRef]

87. Willmann, R.; Lajunen, H.M.; Erbs, G.; Newman, M.; Kolb, D.; Tsuda, K. Arabidopsis lysin-motif proteins LYM1 LYM3 CERK1 mediate bacterial peptidoglycan sensing and immunity to bacterial infection. PNAS 2011, 108, 19824-19829. [CrossRef]

88. Faulkner, C.; Petutschnig, E.; Benitez-Alfonso, Y.; Beck, M.; Robatzek, S.; Lipka, V.; Maule, A.J. LYM2-dependent chitin perception limits molecular flux via plasmodesmata. PNAS 2013, 110, 9166-9170. [CrossRef] 
89. Wan, J.; Tanaka, K.; Zhang, X.; Son, G.H.; Brechenmacher, L.; Hong, T.; Nguyen, N.; Stacey, G. LYK4, a lysin motif receptor-like kinase, is important for chitin signaling and plant innate immunity in Arabidopsis. Plant Physiol. 2012, 160, 396-406. [CrossRef]

90. Cao, Y.; Liang, Y.; Tanaka, K.; Nguyen, C.T.; Jedrzejczak, R.P.; Joachimiak, A.; Stacey, G. The kinase LYK5 is a major chitin receptor in Arabidopsis and forms a chitin-induced complex with related kinase CERK1. E-Life 2014, 3, 1-19. [CrossRef]

91. Liu, B.; Li, J.; Ao, Y.; Qu, J.; Li, Z.; Su, J.; Zhang, Y.; Liu, J.; Feng, D.; Qi, K.; et al. Lysin motif-Containing proteins LYP4 and LYP6 play dual roles in peptidoglycan and chitin perception in rice innate immunity. Plant Cell 2012, 24, 3406-3419. [CrossRef]

92. Ranf, S.; Gisch, N.; Schäffer, M.; Illig, T.; Westphal, L.; Knirel, Y.A.; Sánchez-carballo, P.M.; Zähringer, U.; Hückelhoven, R.; Lee, J.; et al. A lectin S-domain receptor kinase mediates lipopolysaccharide sensing in Arabidopsis thaliana. Nat. Imunol. 2015, 16, 426-433. [CrossRef]

93. Kutschera, A.; Dawid, C.; Gisch, N.; Schmid, C.; Raasch, L.; Gerster, T.; Schäffer, M.; Smakowska-Luzan, E.; Belkhadir, Y.; Corina Vlot, A.; et al. Bacterial medium-chain 3-hydroxy fatty acid metabolites trigger immunity in Arabidopsis plants. Science 2019, 364, 178-181. [CrossRef] [PubMed]

94. Sanabria, N.M.; Van Heerden, H.; Dubery, I.A. Molecular characterisation and regulation of a Nicotiana tabacum S-domain receptor-like kinase gene induced during an early rapid response to lipopolysaccharides. Gene 2012, 501, 39-48. [CrossRef] [PubMed]

95. Altenbach, D.; Robatzek, S. Pattern recognition receptors: From the cell surface to intracellular dynamics. Mol. Plant-Microbe Interact. 2007, 20, 1031-1039. [CrossRef] [PubMed]

96. Chinchilla, D.; Zipfel, C.; Robatzek, S.; Kemmerling, B.; Nürnberger, T.; Jones, J.D.G.; Felix, G.; Boller, T. A flagellin-induced complex of the receptor FLS2 and BAK1 initiates plant defence. Nature 2007, 448, 497-500. [CrossRef] [PubMed]

97. Zipfel, C. Early molecular events in PAMP-triggered immunity. Curr. Opin. Plant Biol. 2009, 12, 414-420. [CrossRef] [PubMed]

98. Heese, A.; Hann, D.R.; Gimenez-Ibanez, S.; Jones, A.M.E.; He, K.; Li, J.; Schroeder, J.I.; Peck, S.C.; Rathjen, J.P. The receptor-like kinase SERK3/BAK1 is a central regulator of innate immunity in plants. PNAS 2007, 104, 12217-12222. [CrossRef]

99. Sun, Y.; Lei, L.; Macho, A.; Zhifu, H. Structural basis for flg22-induced activation of the Arabidopsis FLS2-BAK1 immune complex. Science 2013, 342, 624-628. [CrossRef]

100. Wan, W.L.; Fröhlich, K.; Pruitt, R.N.; Nürnberger, T.; Zhang, L. Plant cell surface immune receptor complex signaling. Curr. Opin. Plant Biol. 2019, 50, 18-28. [CrossRef]

101. Liebrand, T.W.H.; Van Den Berg, G.C.M.; Zhang, Z.; Smit, P.; Cordewener, J.H.G.; America, A.H.P.; Sklenar, J.; Jones, A.M.E.; Tameling, W.I.L.; Robatzek, S.; et al. Receptor-like kinase SOBIR1/EVR interacts with receptor-like proteins in plant immunity against fungal infection. PNAS 2013, 110, 10010-10015. [CrossRef]

102. Gao, M.; Wang, X.; Wang, D.; Xu, F.; Ding, X.; Zhang, Z.; Bi, D.; Cheng, Y.T.; Chen, S.; Li, X.; et al. Regulation of cell death and innate immunity by two receptor-like kinases in Arabidopsis. Cell Host Microbe 2009, 6, 34-44. [CrossRef]

103. Liu, Y.; Huang, X.; Li, M.; He, P.; Zhang, Y. Loss-of-function of Arabidopsis receptor-like kinase BIR1 activates cell death and defense responses mediated by BAK1 and SOBIR1. New Phytol. 2016, 212, 637-645. [CrossRef] [PubMed]

104. Yeh, Y.; Panzeri, D.; Kadota, Y.; Huang, Y.; Huang, P.; Tao, C. The Arabidopsis malectin-like/LRR-RLK IOS1 is critical for BAK1-dependent and BAK1-independent pattern-triggered immunity. Plant Cell 2016, 28, 1701-1721. [CrossRef] [PubMed]

105. Stegmann, M.; Monaghan, J.; Smakowska-Luzan, E.; Rovenich, H.; Lehner, A.; Holton, N.; Belkhadir, Y.; Zipfel, C. The receptor kinase FER is a RALF-regulated scaffold controlling plant immune signaling. Science 2017, 355, 287-289. [CrossRef] [PubMed]

106. Phillips, S.M.; Dubery, I.A.; Van Heerden, H. Molecular characterization of an elicitor-responsive Armadillo repeat gene (GhARM) from cotton (Gossypium hirsutum). Mol. Biol. Rep. 2012, 39, 8513-8523. [CrossRef] [PubMed]

107. Lu, D.; Lin, W.; Gao, X.; Wu, S.; Cheng, C.; Avila, J.; Heese, A.; Devarenne, T.P.; He, P.; Shan, L. Direct ubiquitination of pattern recongnition receptor FLS2 attenuates plant innate immunity. Science 2011, 332, 1439-1442. [CrossRef] [PubMed] 
108. Robatzek, S.; Chinchilla, D.; Boller, T. Ligand-induced endocytosis of the pattern recognition receptor FLS2 in Arabidopsis. Genes Dev. 2006, 20,537-542. [CrossRef]

109. Li, W.; Ahn, I.P.; Ning, Y.; Park, C.H.; Zeng, L.; Whitehill, J.G.A.; Lu, H.; Zhao, Q.; Ding, B.; Xie, Q.; et al. The U-Box/ARM E3 ligase PUB13 regulates cell death, defense, and flowering time in Arabidops. Plant Physiol. 2012, 159, 239-250. [CrossRef]

110. Liu, J.; Li, W.; Ning, Y.; Shirsekar, G.; Cai, Y.; Wang, X.; Dai, L.; Wang, Z.; Liu, W.; Wang, G.L. The U-box E3 ligase SPL11/PUB13 is a convergence point of defense and flowering signaling in plants. Plant Physiol. 2012, 160, 28-37. [CrossRef]

111. Liao, D.; Cao, Y.; Sun, X.; Espinoza, C.; Nguyen, C.T.; Liang, Y.; Stacey, G. Arabidopsis E3 ubiquitin ligase PLANT U-BOX13 (PUB13) regulates chitin receptor lysin motif receptor kinase 5 (LYK5) protein abundance. New Phytol. 2017, 214, 1646-1656. [CrossRef]

112. Zhou, B.; Zeng, L. The tomato U-box type E3 ligase PUB13 acts with group III ubiquitin E2 enzymes to modulate FLS2-mediated immune signaling. Front. Plant Sci. 2018, 9, 615. [CrossRef]

113. Trujillo, M.; Ichimura, K.; Casais, C.; Shirasu, K. Negative regulation of PAMP-triggered immunity by an E3 ubiquitin ligase triplet in Arabidopsis. Curr. Biol. 2008, 18, 1396-1401. [CrossRef] [PubMed]

114. Lacombe, S.; Rougon-cardoso, A.; Sherwood, E.; Peeters, N.; Dahlbeck, D.; Van Esse, H.P.; Smoker, M.; Rallapalli, G.; Thomma, B.P.H.J.; Staskawicz, B.; et al. Interfamily transfer of a plant pattern-recognition receptor confers broad-spectrum bacterial resistance. Nat. Biotechnol. 2010, 28, 365-369. [CrossRef] [PubMed]

115. Rodriguez-Moreno, L.; Song, Y.; Thomma, B.P. Transfer and engineering of immune receptors to improve recognition capacities in crops. Curr. Opin. Plant Biol. 2017, 38, 42-49. [CrossRef] [PubMed]

116. Che, F.S.; Nakajima, Y.; Tanaka, N.; Iwano, M.; Yoshida, T.; Takayama, S.; Kadota, I.; Isogai, A. Flagellin from an incompatible strain of Pseudomonas avenae induces a resistance response in cultured rice cells. J. Biol. Chem. 2000, 275, 32347-32356. [CrossRef] [PubMed]

117. Chinchilla, D.; Bauer, Z.; Regenass, M.; Boller, T.; Felix, G. The Arabidopsis receptor kinase FLS2 binds flg22 and determines the specificity of flagellin perception. Plant Cell 2006, 18, 465-476. [CrossRef] [PubMed]

118. Zipfel, C.; Robatzek, S.; Navarro, L.; Oakeley, E.J.; Jones, J.D.G.; Felix, G.; Boller, T. Bacterial disease resistance in Arabidopsis through flagellin perception. Nature 2004, 428, 764-767. [CrossRef]

119. Kunze, G. The $\mathrm{N}$ terminus of bacterial Elongation Factor Tu elicits innate immunity in Arabidopsis plants. Plant Cell 2004, 16, 3496-3507. [CrossRef]

120. Furukawa, T.; Inagaki, H.; Takai, R.; Hirai, H.; Che, F. Two distinct EF-Tu epitopes induce immune responses in rice and Arabidopsis. MPMI. 2014, 27, 113-124. [CrossRef]

121. Jeworutzki, E.; Roelfsema, M.R.G.; Anschütz, U.; Krol, E.; Elzenga, J.T.M.; Felix, G.; Boller, T.; Hedrich, R.; Becker, D. Early signaling through the Arabidopsis pattern recognition receptors FLS2 and EFR involves $\mathrm{Ca}^{2}+$-associated opening of plasma membrane anion channels. Plant J. 2010, 62, 367-378. [CrossRef]

122. Lee, C.; Mannaa, M.; Kim, N.; Kim, J.; Choi, Y.; Kim, S.H.; Jung, B.; Lee, H.; Lee, J.; Seo, Y. Stress tolerance and virulence-related roles of lipopolysaccharide in Burkholderia glumae. Plant Pathol. J 2019, 35, 445-458. [CrossRef]

123. Ranf, S. Immune sensing of lipopolysaccharide in plants and animals: Same but different. PLoS Pathog. 2016, 12, 1-7. [CrossRef]

124. Weiss, J. Bactericidal/permeability-increasing protein (BPI) and lipopolysaccharide-binding protein (LBP): Structure, function and regulation in host defence against Gram-negative bacteria. Biochem. Soc. Trans. 2003, 31, 785-790. [CrossRef] [PubMed]

125. Elsbach, P.; Weiss, J. Role of the bactericidal/permeability-increasing protein in host defence. Curr. Opin. Immunol. 1998, 10, 45-49. [CrossRef] [PubMed]

126. Madala, N.E.; Leone, M.R.; Molinaro, A.; Dubery, I.A. Deciphering the structural and biological properties of the lipid A moiety of lipopolysaccharides from Burkholderia cepacia strain ASP B 2D, in Arabidopsis thaliana. Glycobiology 2011, 21, 184-194. [CrossRef] [PubMed]

127. Madala, N.E.; Molinaro, A.; Dubery, I.A. Distinct carbohydrate and lipid-based molecular patterns within lipopolysaccharides from Burkholderia cepacia contribute to defense-associated differential gene expression in Arabidopsis thaliana. Innate Immun. 2011, 18, 140-154. [CrossRef]

128. Lizasa, S.; Lizasa, E.; Matsuzaki, S.; Tanaka, H.; Kodama, Y.; Watanabe, K.; Nagano, Y. Arabidopsis LBP/BPI related-1 and -2 bind to LPS directly and regulate PR1 expression. Sci. Rep. 2016, 6, 1-10. [CrossRef] 
129. Shang-Guan, K.; Wang, M.; Htwe, N.M.P.S.; Li, P.; Li, Y.; Qi, F.; Zhang, D.; Cao, M.; Kim, C.; Weng, H.; et al. Lipopolysaccharides trigger two successive bursts of reactive oxygen species at distinct cellular locations. Plant Physiol. 2018, 176, 2543-2556. [CrossRef]

130. Zeidler, D.; Zahringer, U.; Gerber, I.; Dubery, I.; Hartung, T.; Bors, W.; Hutzler, P.; Durner, J. Innate immunity in Arabidopsis thaliana: Lipopolysaccharides activate nitric oxide synthase (NOS) and induce defense genes. PNAS 2004, 101, 15811-15816. [CrossRef]

131. Gerber, I.B.; Zeidler, D.; Durner, J.; Dubery, I.A. Early perception responses of Nicotiana tabacum cells in response to lipopolysaccharides from Burkholderia cepacia. Planta 2004, 218, 647-657. [CrossRef]

132. Desaki, Y.; Miya, A.; Venkatesh, B.; Tsuyumu, S.; Yamane, H.; Kaku, H.; Minami, E.; Shibuya, N. Bacterial lipopolysaccharides induce defense responses associated with programmed cell death in rice cells. Plant Cell Physiol. 2006, 47, 1530-1540. [CrossRef]

133. Melotto, M.; Underwood, W.; Koczan, J.; Nomura, K.; He, S.Y. Plant stomata function in innate immunity against bacterial invasion. Cell 2006, 126, 969-980. [CrossRef] [PubMed]

134. Vilakazi, C.S.; Dubery, I.A.; Piater, L.A. Identification of lipopolysaccharide-interacting plasma membrane-type proteins in Arabidopsis thaliana. Plant Physiol. Biochem. 2017, 111, 155-165. [CrossRef] [PubMed]

135. Baloyi, N.M.; Dubery, I.A.; Piater, L.A. Proteomic analysis of Arabidopsis plasma membranes reveals lipopolysaccharide-responsive changes. Biochem. Biophys. Res. Commun. 2017, 486, 1137-1142. [CrossRef] [PubMed]

136. Lizasa, S.; Lizasa, E.; Watanabe, K.; Nagano, Y. Transcriptome analysis reveals key roles of AtLBR-2 in LPS-induced defense responses in plants. BMC Genom. 2017, 18, 1-13. [CrossRef]

137. Desaki, Y.; Kouzai, Y.; Ninomiya, Y.; Iwase, R.; Shimizu, Y.; Seko, K.; Molinaro, A.; Minami, E.; Shibuya, N.; Kaku, H.; et al. OsCERK1 plays a crucial role in the lipopolysaccharide-induced immune response of rice. New Phytol. 2018, 217, 1042-1049. [CrossRef]

138. Ao, Y.; Li, Z.; Feng, D.; Xiong, F.; Liu, J.; Li, J.F.; Wang, M.; Wang, J.; Liu, B.; Wang, H. OsCERK1 and OsRLCK176 play important roles in peptidoglycan and chitin signaling in rice innate immunity. Plant J. 2014, 80, 1072-1084. [CrossRef]

139. Yamada, A.; Shibuya, N.; Kodama, O.; Akatsuka, T. Induction of phytoalexin formation in suspension-cultured rice cells by $\mathrm{N}$-acetylchitooligosaccharides. Biosci. Biotechnol. Biochem. 1993, 57, 405-409. [CrossRef]

140. Liu, T.; Liu, Z.; Song, C.; Hu, Y.; Han, Z.; She, J.; Fan, F.; Wang, J.; Jin, C.; Chang, J.; et al. Chitin-induced dimerization activates a plant immune receptor. Science 2012, 336, 1160-1165. [CrossRef]

141. Petutschnig, E.K.; Jones, A.M.E.; Serazetdinova, L.; Lipka, U.; Lipka, V. The lysin motif receptor-like kinase (LysM-RLK) CERK1 is a major chitin-binding protein in Arabidopsis thaliana and subject to chitin-induced phosphorylation. J. Biol. Chem. 2010, 285, 28902-28911. [CrossRef]

142. Antolín-Llovera, M.; Ried, M.K.; Binder, A.; Parniske, M. Receptor kinase signaling pathways in plant-microbe interactions. Annu. Rev. Phytopathol. 2012, 50, 451-473. [CrossRef]

143. Tanaka, K.; Nguyen, C.T.; Liang, Y.; Cao, Y.; Stacey, G. Role of LysM receptors in chitin-triggered plant innate immunity. Plant Signal. Behav. 2013, 8, e22598. [CrossRef] [PubMed]

144. Wan, J.; Zhang, X.; Neece, D.; Ramonell, K.M.; Clough, S.; Kim, S.; Stacey, M.G.; Stacey, G. A lysM receptor-like kinase plays a critical role in chitin signaling and fungal resistance in Arabidopsis. Plant Cell 2008, 20 , 471-481. [CrossRef] [PubMed]

145. Narusaka, Y.; Shinya, T.; Narusaka, M.; Motoyama, N.; Shimada, H.; Murakami, K. Presence of LYM2 dependent but CERK1 independent disease resistance in Arabidopsis. Plant Signal. Behav. 2013, 8, e25345. [CrossRef]

146. Shinya, T.; Motoyama, N.; Ikeda, A.; Wada, M.; Kamiya, K.; Hayafune, M.; Kaku, H.; Shibuya, N. Functional characterization of CEBiP and CERK1 homologs in Arabidopsis and rice reveals the presence of different chitin receptor systems in plants. Plant Cell Physiol. 2012, 53, 1696-1706. [CrossRef] [PubMed]

147. Le, M.H.; Cao, Y.; Zhang, X.; Stacey, G. LIK1, a CERK1-interacting kinase, regulates plant immune responses in Arabidopsis. PLoS ONE 2014, 9, e102245. [CrossRef] [PubMed]

148. Glazebrook, J. Contrasting mechanisms of defense against biotrophic and necrotrophic pathogens. Annu. Rev. Phytopathol. 2005, 43, 205-227. [CrossRef]

149. Ray, J.; Yang, X.; Kong, F.; Guo, T.; Deng, F.; Clough, S.; Ramonell, K. A novel receptor-like kinase involved in fungal pathogen defence in Arabidopsis thaliana. J. Phytopathol. 2018, 166, 506-515. [CrossRef] 
150. Li, J.; Wen, J.; Lease, K.A.; Doke, J.T.; Tax, F.E.; Walker, J.C. BAK1, an Arabidopsis LRR receptor-like protein kinase, interacts with BRI1 and modulates brassinosteroid signaling. Cell 2002, 110, 213-222. [CrossRef]

151. Nam, K.H.; Li, J. BRI1/BAK1, a receptor kinase pair mediating brassinosteroid signaling. Cell 2002, 110, 203-212. [CrossRef]

152. Roux, M.; Schwessinger, B.; Albrecht, C.; Chinchilla, D.; Jones, A.; Holton, N.; Malinovsky, F.G.; Tör, M.; De Vries, S.; Zipfel, C. The Arabidopsis leucine-rich repeat receptor-Like kinases BAK1/SERK3 and BKK1/SERK4 are required for innate immunity to hemibiotrophic and biotrophic pathogens. Plant Cell 2011, 23, 2440-2455. [CrossRef]

153. Dressano, K.; Ceciliato, P.H.O.; Silva, A.L.; Guerrero-Abad, J.C.; Bergonci, T.; Ortiz-Morea, F.A.; Bürger, M.; Silva-Filho, M.C.; Moura, D.S. BAK1 is involved in AtRALF1-induced inhibition of root cell. PLoS Genet. 2017, 13, e1007053. [CrossRef] [PubMed]

154. Liebrand, T.W.H.; Van den Burg, H.A.; Joosten, M.H.A.J. Two for all: Receptor-associated kinases SOBIR1 and BAK1. Trends Plant Sci. 2014, 19, 123-132. [CrossRef] [PubMed]

155. Kemmerling, B.; Schwedt, A.; Rodriguez, P.; Mazzotta, S.; Frank, M.; Qamar, S.A.; Mengiste, T.; Betsuyaku, S.; Parker, J.E.; Müssig, C.; et al. The BRI1-associated kinase 1, BAK1, has a brassinolide-independent role in plant cell-death control. Curr. Biol. 2007, 17, 1116-1122. [CrossRef] [PubMed]

156. He, K.; Gou, X.; Yuan, T.; Lin, H.; Asami, T.; Yoshida, S.; Russell, S.D.; Li, J. BAK1 and BKK1 regulate brassinosteroid-dependent growth and brassinosteroid-independent cell-death pathways. Curr. Biol. 2007, 17, 1109-1115. [CrossRef]

157. Du, J.; Gao, Y.; Zhan, Y.; Zhang, S.; Wu, Y.; Xiao, Y.; Zou, B.; He, K.; Gou, X. Nucleocytoplasmic trafficking is essential for BAK1- and BKK1-mediated cell-death control. Plant J. 2016, 85, 520-531. [CrossRef]

158. Veronese, P.; Nakagami, H.; Bluhm, B.; AbuQamar, S.; Chen, X.; Salmeron, J.; Dietrich, R.A.; Hirt, H.; Mengiste, T. The membrane-anchored Botrytis-induced kinase1 plays distinct roles in Arabidopsis resistance to necrotrophic and biotrophic pathogens. Plant Cell 2006, 18, 257-273. [CrossRef]

159. Chen, T.; Bi, K.; He, Z.; Gao, Z.; Zhao, Y.; Fu, Y.; Cheng, J.; Xie, J.; Jiang, D. Arabidopsis mutant bik1 exhibits strong resistance to Plasmodiophora brassicae. Front. Physiol. 2016, 7, 1-13. [CrossRef]

160. Zhang, W.; Fraiture, M.; Kolb, D.; Löffelhardt, B.; Desaki, Y.; Boutrot, F.F.G.; Tör, M.; Zipfel, C.; Gust, A.A.; Brunner, F. Arabidopsis receptor-like protein 30 and receptor-like kinase suppresor of bir1-1/evershed mediate innate immunity to necrotrophic fungi. Plant Cell 2013, 25, 4227-4241. [CrossRef]

161. Xiao, Y.; Stegmann, M.; Han, Z.; DeFalco, T.A.; Parys, K.; Xu, L.; Belkhadir, Y.; Zipfel, C.; Chai, J. Mechanisms of RALF peptide perception by a heterotypic receptor complex. Nature 2019, 572, 270-274. [CrossRef]

162. Guo, H.; Nolan, T.M.; Song, G.; Schnable, P.S.; Walley, J.W.; Yin, Y.; Guo, H.; Nolan, T.M.; Song, G.; Liu, S.; et al. FERONIA receptor kinase contributes to plant immunity by suppressing jasmonic acid signaling in Arabidopsis thaliana. Curr. Biol. 2018, 28, 3316-3324. [CrossRef] 